\title{
An integrated magnetic susceptibility anisotropy (AMS) and structural geological study on Cenozoic clay-rich sediments from the Transdanubian Range
}

\author{
Krisztina Sipos-Benkô ${ }^{1}$, Emô Márton ${ }^{1}$, László I. Fodor ${ }^{2}$, Mihály Pethe ${ }^{3}$ \\ ${ }^{1}$ Paleomagnetic Laboratory, Geological and Geophysical Institute of Hungary, Budapest, Hungary \\ ${ }^{2}$ Geological, Geophysical and Space Science, Research Group of the Hungarian Academy of Sciences, Eötvös \\ Loránd University, Budapest, Hungary \\ ${ }^{3}$ Department of Geophysics, Eötvös Loránd University, Budapest, Hungary
}

\begin{abstract}
Systematic structural and anisotropy of magnetic susceptibility (AMS) measurements were carried out on Cenozoic clay-rich deposits from the Transdanubian Range, central part of the Alcapa Unit. The aim was to improve the knowledge of the Neogene tectonic evolution of the area and of the connection of the stress field and the magnetic fabric of the sediments. The measurements of AMS revealed dominant foliation with weak lineation for Middle Eocene-Lower Miocene sediments. The directions of AMS lineation are aligned either with the direction of NNE-SSW extension of a strike slip phase (30-19 Ma) or with the direction of NE-SW extension of the main rifting phase of the Pannonian Basin (19-14 Ma).

The studied Late Miocene sediments have foliated AMS fabric, maximum and intermediate AMS directions are intermixed, and the AMS fabrics do not show any sign of tectonic deformation. In contrast, joints and faults were observed in the same rocks. Detailed structural analysis shows two extensional phases between ca. 10-4 Ma, with E-W to WNW-ESE and with NW-SE extension, respectively, and the youngest neotectonic strike-slip phase. The contrast between the presence of markers of brittle deformation and the absence of tectonically-induced AMS lineation is striking, since the same types of sediments in the South Pannonian basin show just the opposite. The explanation may be that northward-moving and CCW-rotating Adria caused strong compression in the southern Pannonian Basin, resulting in ductile deformation of the clay-rich sediments and systematic reorganization of AMS texture, while in our study area sediments of similar character and age were at a larger distance from the strongly deforming basin part.
\end{abstract}

Key words: integrated, magnetic susceptibility, anisotropy, AMS, structural geology, fault-slip analysis, Cenozoic, Transdanubian Range

\footnotetext{
Addresses: K. Sipos-Benkő, E. Márton: H-1118 Budapest, Homonna u. 9, Hungary; e-mails: siposbenko.krisztina@gmail.com,paleo@mfgi.hu L. I. Fodor: H-1117 Budapest, Pázmány P. stny 1/c, Hungary; e-mail: lasz.fodor@yahoo.com

M. Pethe: H-1117 Budapest, Pázmány P. stny 1/c, Hungary; e-mail: mifimester@gmail.com

Received: July 27, 2013, accepted: February 5, 2014
} 


\section{Introduction}

Several studies establish the anisotropy of magnetic susceptibility (AMS) as a reliable marker of strain (e.g. Kissel et al. 1986; Hrouda 1987; Hirt et al. 1988; Lee et al. 1990). However, not only the tectonic deformation but also other geologic processes, such as deposition, compaction, running water can form the AMS of rocks (Hrouda 1987; Tarling and Hrouda 1993). As a result, the magnetic fabric becomes complex and the separation of deformational and non-deformational parts requires sophisticated methods (Hrouda 1987; Bordás 1992). Fortunately the magnetic fabric of the clay-rich sediments affected by weak deformation is relatively simple. The dominant feature is foliation due to deposition and compaction, while magnetic lineation has consistent orientation in different samples and in different strata of the same outcrop. The magnetic lineation marks the direction of extension (Sagnotti et al. 1994; Mattei et al. 1997; Pethe et al. 2009; Borradaile and Jackson 2010; Márton et al. 2011; Sipos-Benkố et al. 2012). In extensional settings the AMS lineation is generally orthogonal to the main normal faults and parallel with the stretching direction of the basin, and has been interpreted as a tectonic feature formed in clayey sediments during the early stages of extensional basin development (Cifelli et al. 2004).

Tectonic deformation is also manifested by brittle structures, such as faults and associated joint systems. These features can be observed in the field and evaluated from the viewpoint of the type of stress field and orientation of the principal stress axes. It commonly occurs that several consecutive deformation events leave their imprint on a sediment.

The aim of the present paper is to investigate at locality level whether the two independent methods, the study of the magnetic anisotropy and fault-slip analysis, provide the same values for the orientation of the extension direction in the Cenozoic clay-rich sediments of the Transdanubian Range. A positive answer to this question would establish the AMS lineation as a reliable marker of the extension direction. Thus, AMS lineation could be confidently used as a proxy for minimum stress axis in outcrops where the outcrop-scale markers of brittle deformation are lacking.

\section{Geologic and tectonic settings}

The Transdanubian Range consists of isolated hills. They are the Balaton Highlands, Bakony, Vértes, Velence, Gerecse, Buda, Pilis and Visegrád Hills (Fig. 1). The Cenozoic sedimentary cycle began with the accumulation of bauxite (Mindszenty et al. 1988), which was followed by deposition of parallic coal, alluvial and shallow-marine conglomerate and sandstone in the Middle Eocene. These sediments are overlain by neritic limestone and marl (Dudich and Kopek 1980; Báldi 1986). During the earliest Oligocene the area west of the Buda Line was uplifted and denudation removed the top part of the Eocene sequences (Telegdi Roth 1927). Starting from the late Early Oligocene fluvial gravel, sand and 
variegated clay were deposited in considerable thickness (400-800 m, Csatka Formation; Korpás 1981) in the western and central Transdanubian Range. It passes laterally to marginal marine, local brackish sandstone, silt(stone) and clay (Mány Fm.) while deep water marine sedimentation continued in the eastern Buda Hills (east of the Buda Line; e.g. Báldi 1986; Tari et al. 1993, Fig. 1). Most of the studied Oligocene sites belong to the Csatka or Mány Formations.

From the late Early or Middle Miocene (Karpatian or Badenian using local Paratethys stages; see Nagymarosy 1990) marine sedimentation occurred again in some semi-isolated depressions (Kókay 1991). The coarse clastic base is covered by shallow-water carbonates, which pass upward or laterally to moderately deep marly or clayey sediments. Except in the Buda and Gerecse Hills, the upper Middle Miocene (Sarmatian) is often missing, or represented by terrestrial sediments. The sedimentation style changed in the Late Miocene when lacustrine clay and marl were deposited in the large Lake Pannon (Jámbor 1980; Magyar et al. 1999). The lake was filled by deltas prograding generally from the NW and which deposited sand-rich sediments on the shelves and deep basins, which were connected by channels on the slope itself (Szentgyörgyi and Juhász 1988; Vakarcs et al. 1994; Magyar et al. 1999, 2013; Uhrin and Sztanó 2007). Basalt volcanism began in the latest Miocene but was most intensive in the Pliocene (Balogh et al. 1983; Harangi et al. 1995; Németh and Martin 1999; Wijbrans et al. 2007).

The general structural development of the Transdanubian Range is known from previous publications (e.g. Márton and Fodor 2003; Fodor 2008, 2010) and is concisely presented in the Appendix of the present paper. According to these studies, 13 phases of deformation can be distinguished. The first five phases are Mesozoic, while phases D6-D13 are of Cenozoic age. They are considered as having affected the Transdanubian Range, and according to Fodor (2010), the entire Pannonian Basin in a relatively uniform manner. As we will discuss later, the present research slightly refined the evolution of the stress field of the Transdanubian Range, which has a consequence for the structural evolution of the entire Pannonian Basin.

\section{Methodology}

Anisotropy of magnetic susceptibility (AMS)

The AMS can be described by a second rank symmetric tensor and is represented geometrically by an ellipsoid with the principal axes $\mathrm{k}_{\max }>\mathrm{k}_{\mathrm{int}}>$ $\mathrm{k}_{\text {min' }}$, where $\mathrm{k}_{\max }=\mathrm{k}_{1}, \mathrm{k}_{\text {int }}=\mathrm{k}_{2}, \mathrm{k}_{\min }=\mathrm{k}_{3}$ are magnetic susceptibilities in SI units. The shape of AMS ellipsoids and the degree of the anisotropy can be described by several parameters, most of these having different definitions. In the present paper we are using the following: degree of magnetic anisotropy $(\mathrm{P}): \mathrm{k}_{1} / \mathrm{k}_{3}$, degree of lineation (L): $\mathrm{k}_{1} / \mathrm{k}_{2}$, degree of foliation $(\mathrm{F}): \mathrm{k}_{2} / \mathrm{k}_{3}$ (see e.g. Tarling and Hrouda 1993). 


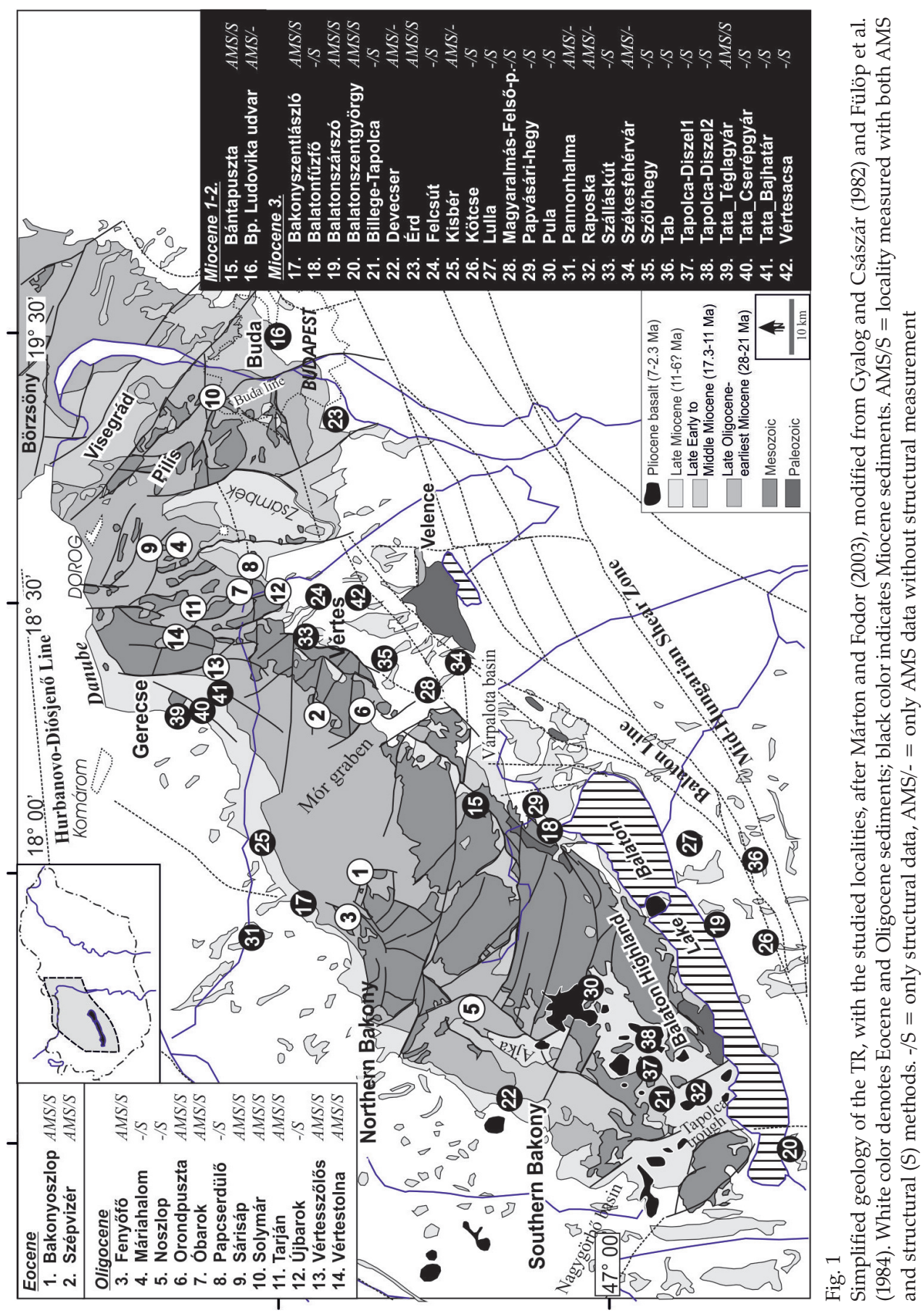


The investigated sediments are shallow marine or fluvial deposits; thus we can exclude gravitational mass movements. The magnetic fabric of a sedimentary rock can be depositional with no current orienting the grains (Fig. 2/a); the only forces operating are gravitational and magnetic. In this case the magnetic fabric is foliated and $k_{\max }$ and $k_{\text {int }}$ are intermixed at locality level. When a current flow operates, the hydraulic forces tend to align elongated particles parallel to the direction of the flow (Fig. 2/b). If sediments undergo tectonic deformation, the fabric will change according to Fig. 2/c/1-4. The stress associated with the progressive ductile deformation induces strain in the material, which influences the magnetic fabric. While for moderate shortening the intermediate and maximum directions are well separated (Fig. 2/c/1), increasing pressure leads to interchange between the minimum and intermediate directions (Fig. 2/c/2-4).

In this study the principal axes of the AMS ellipsoid were determined from the measurements of the magnetic susceptibility of oriented specimens in 15 different positions with a Kappabridge KLY-2 (AGICO, Brno, Czech Republic) in the paleomagnetic laboratory of the Hungarian Geological and Geophysical Institute of Hungary. The results were evaluated at sample level with a computer program based on Jelínek (1977), and at locality level using the Anisoft 4.2 software (Chadima and Jelínek 2008) based on the theoretical work of Jelínek (1978).

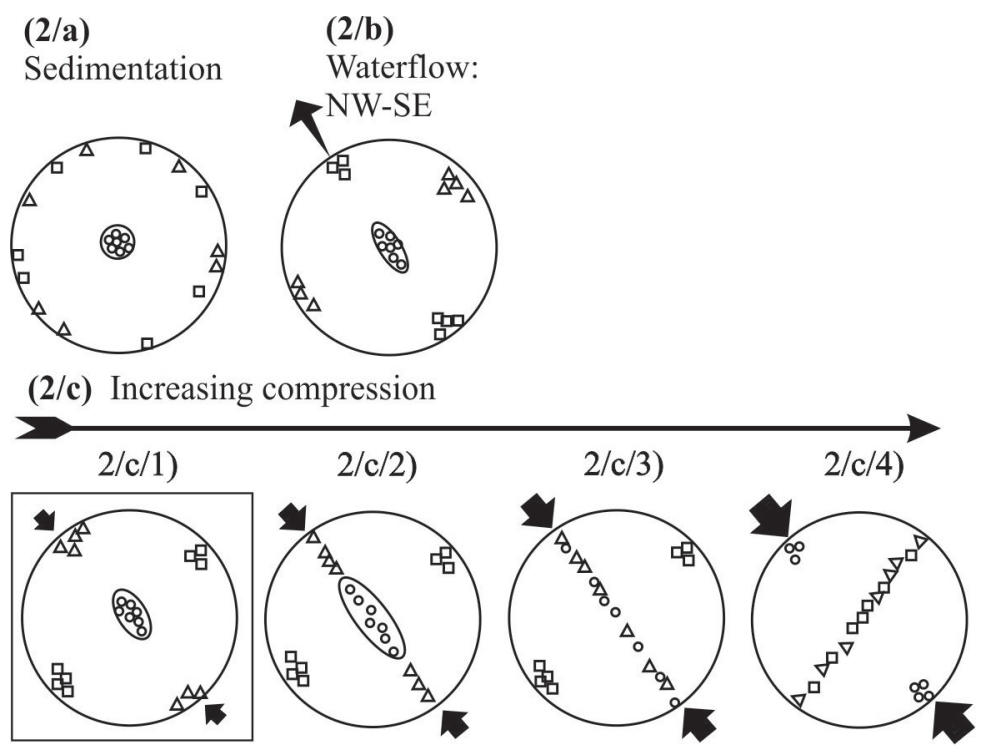

Fig. 2

Sedimentation texture (2/a) is without any lineation. The flow $(2 / b)$ and increasing pressure $(2 / \mathrm{c})$ has an effect on the texture of the AMS. $\square: \mathrm{k}_{1}=$ maximum principal axes, $\mathrm{k}_{\max } /$ mean direction of $\mathrm{k}_{1}$, $\triangle: \mathrm{k}_{2}=$ intermediate principal axes, $\mathrm{k}_{\text {int }} /$ mean direction of $\mathrm{k}_{2}, \mathrm{O}: \mathrm{k}_{3}=$ minimum principal axes, $\mathrm{K}_{\mathrm{min}} /$ mean direction of $\mathrm{k}^{3}$. This paper focuses on the situation plotted in the boxed stereogram 


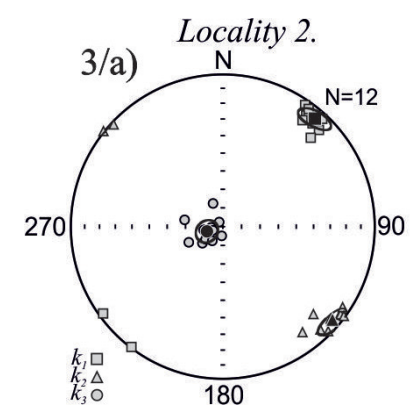

Fig. 3

Typical AMS patterns for the studied localities in the Transdanubian Range. $\mathrm{k}_{1}, \mathrm{k}_{2}, \mathrm{k}_{3}$ : AMS principal axes (max, int, min), $\mathrm{N}$ : number of measurements

For the study a total of 233 samples of clay and marly clay sediments, collected from 22 outcrops, were used. The AMS measurements were carried out on several independently oriented samples from an outcrop in order to facilitate statistical evaluation of the results. For each sampled bed, the dip angle and the dip direction were recorded.

\section{Structural analysis}

In order to refine the Cenozoic tectonic evolution of Transdanubian Range, systematic structural measurements were carried out in 36 localities (Fig. 1): 2 localities in Eocene (Fig. 5), 12 localities in Oligocene (Fig. 5) and 22 in Miocene outcrops (Figs 6 and 7). Observation were made on striated fault surfaces, tensional or shear joints, mineral veins, sedimentary dykes, together with measuring the dip angle and the dip direction of the layers. The fault-slip data were analyzed using the computer software by Angelier $(1984,1989)$. The best fitting stress tensor for a given group of striated faults was calculated by maximizing the shear stress in the direction of the striae (direct inversion method; Angelier 1990). Automatic (Angelier and Manoussis 1980) and interactive phase separations were used equally when two or sometimes three phases were distinguished. Approximation of projected stress axes were made when kinematic indicators for faults were scarce, using the model of Anderson (1951). We used the word tension for the smallest compression ( $\sigma_{3}$ eigenvalue) of the stress tensor. With the word extension (shortening) we emphasize a kinematic process under tension (respectively under compression; Howell et al. 2009)

The fault patterns, outcrop-scale tectonic observations and combination of the information of regional geology and stress field evolution permitted classifying

Fig. $4 \rightarrow$

Structural phases and structural evolution in the Transdanubian Range by Fodor $(2008,2010)$. Note typical stereograms from the studied localities and comparative data from Sasvári et al. (2007) 


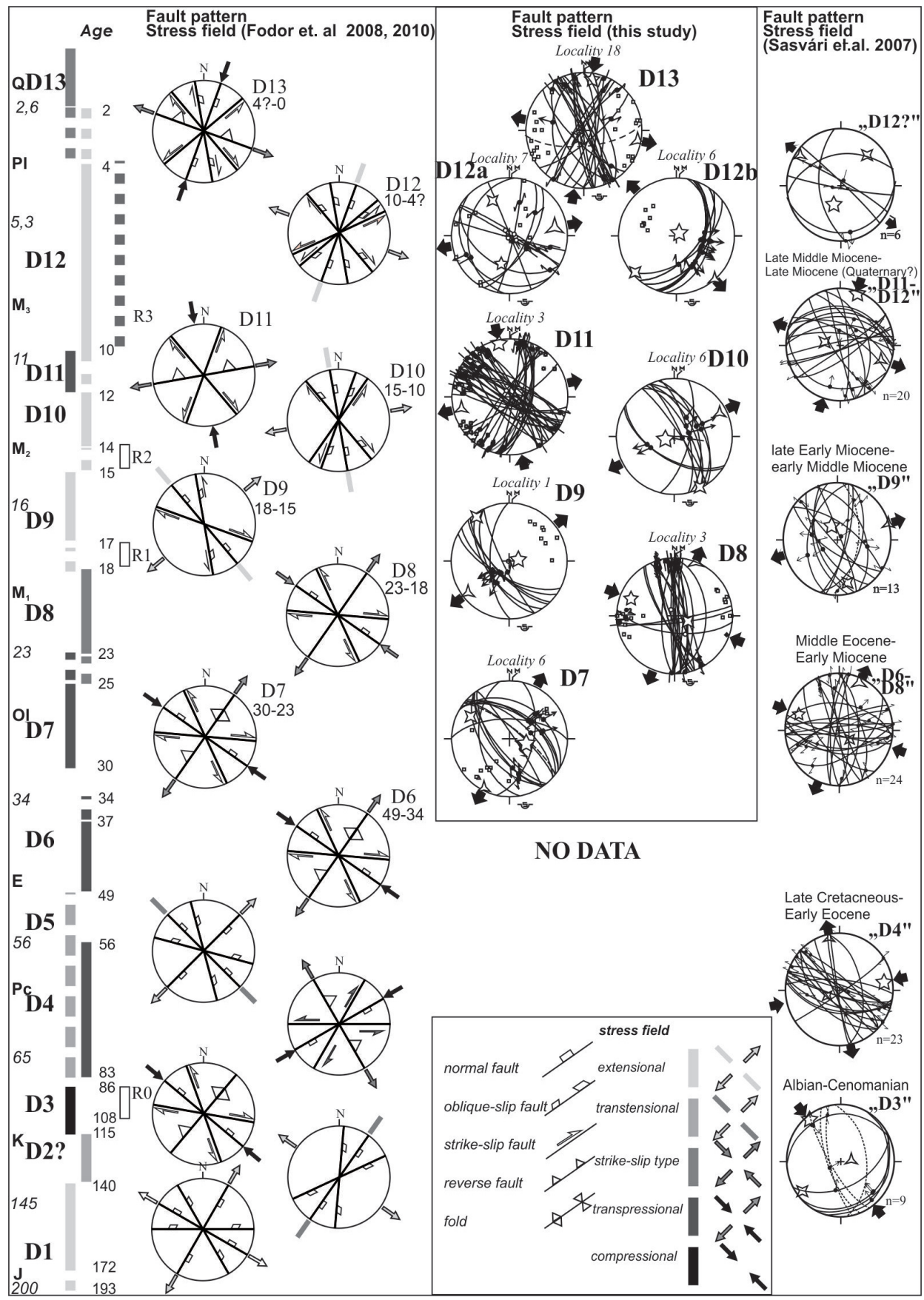




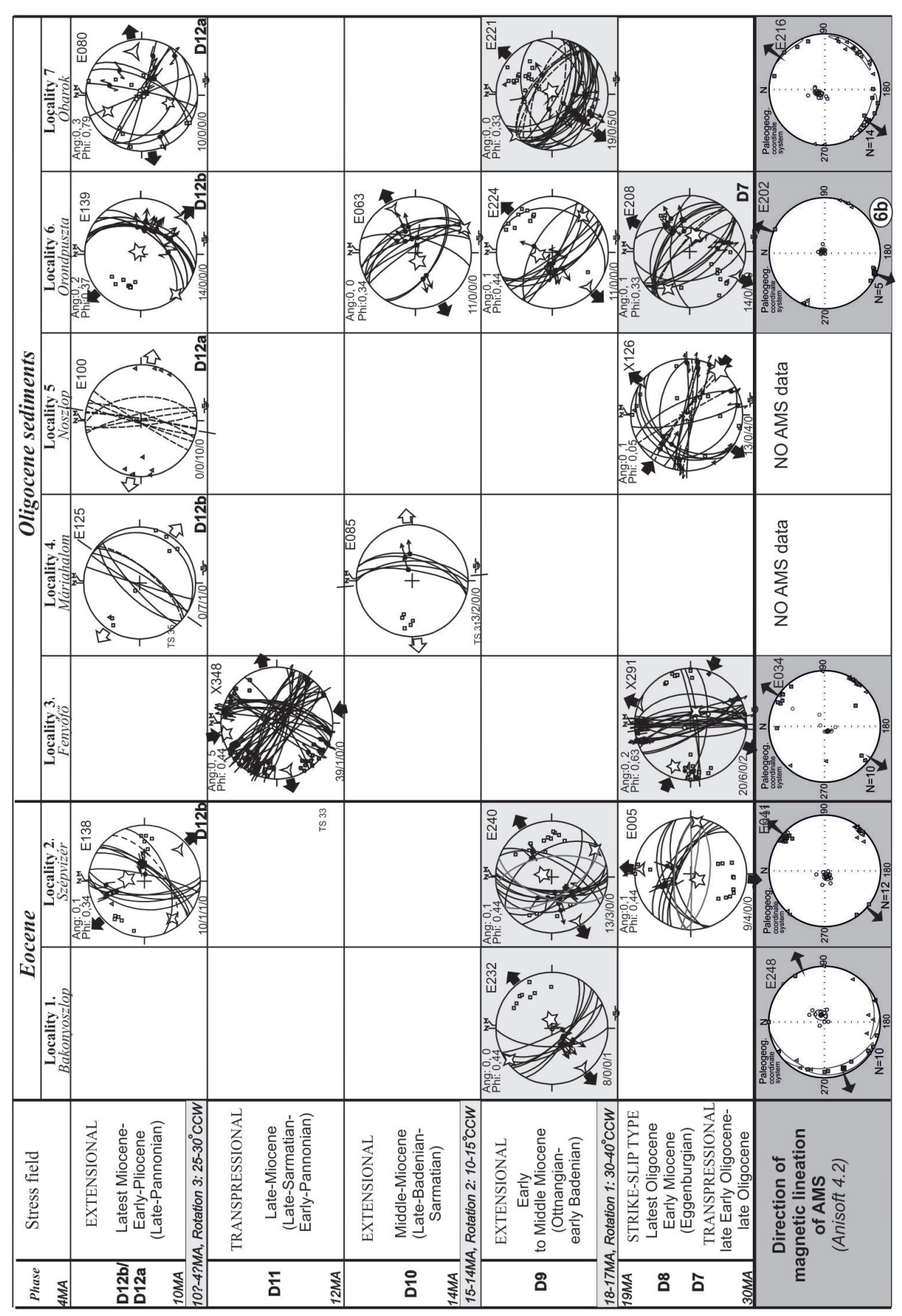

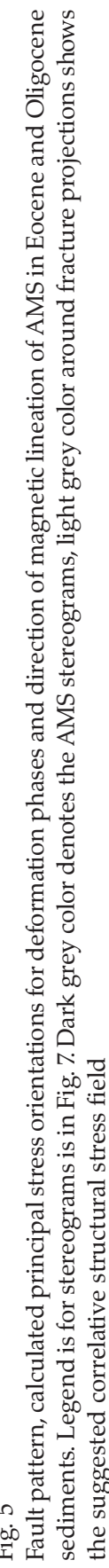


An integrated magnetic susceptibility anisotropy (AMS) and structural geological study 29

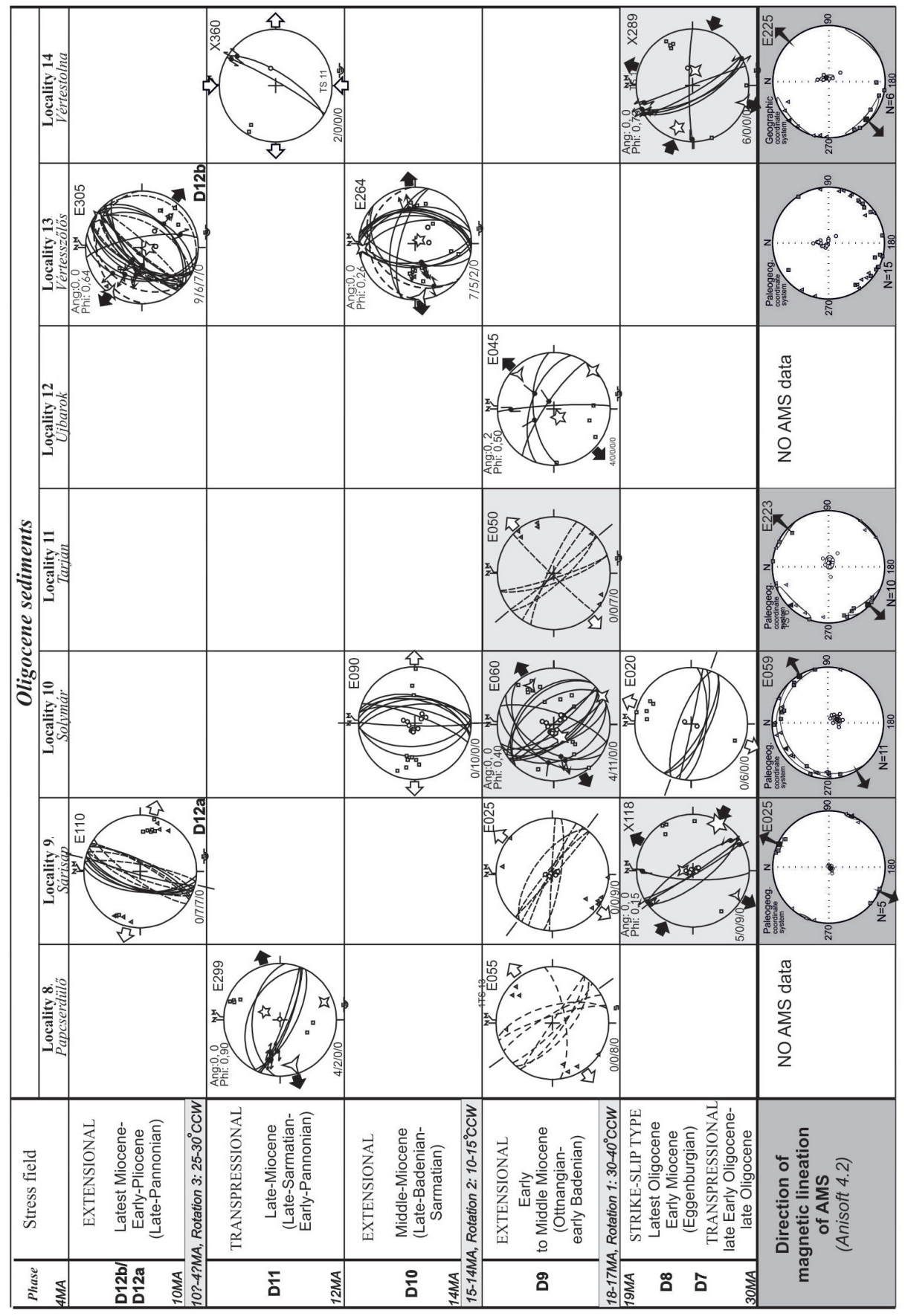

$\dot{\Xi}$
0
0
60
10 


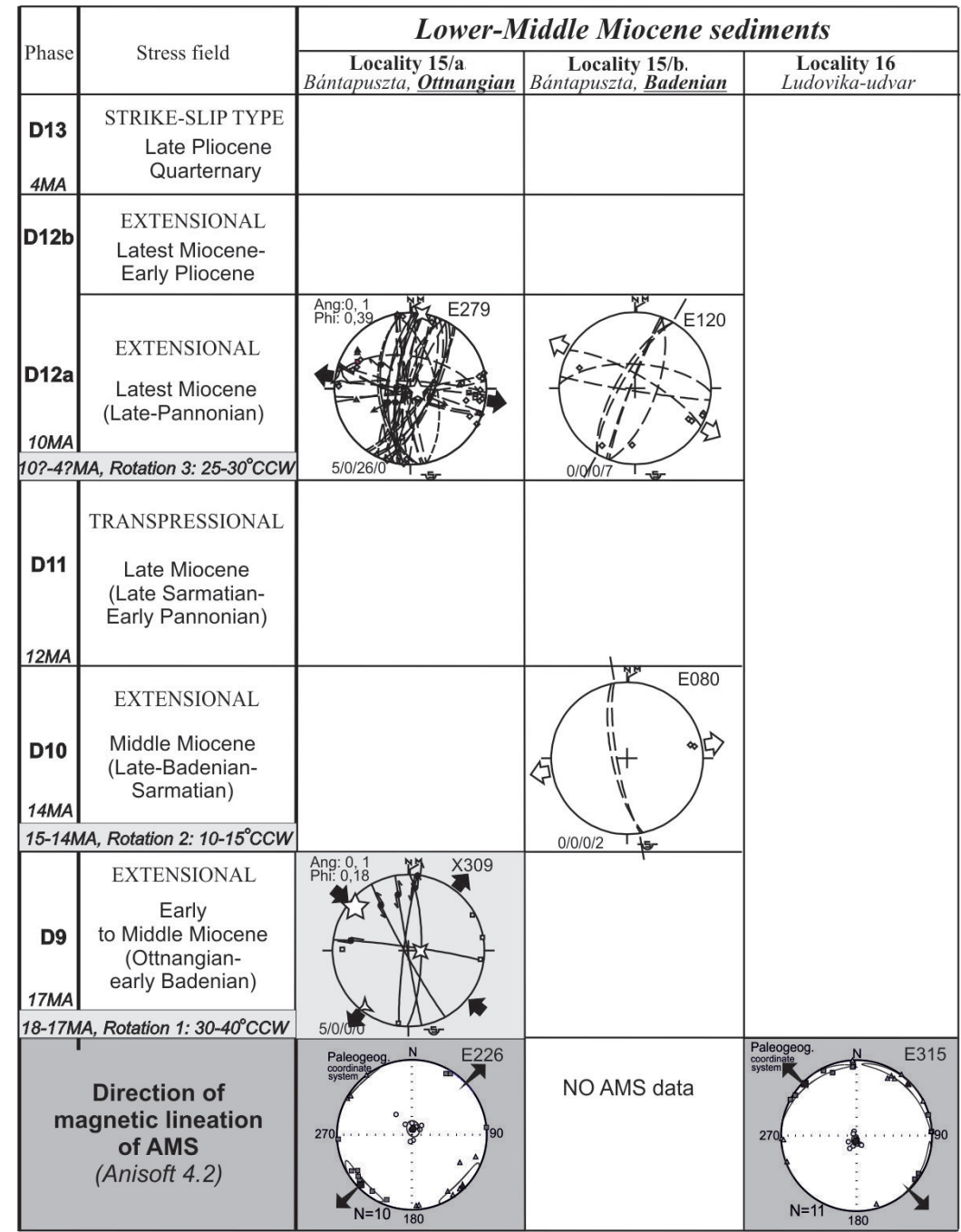

Fig. 6

Calculated principal stress axes for deformation phases and direction of magnetic lineation of AMS in Lower and Middle Miocene sediments. Legend is in Fig. 7. Dark grey color denotes the AMS stereograms, light grey color shows the suggested structural stress field

pointed out similarities and differences with respect to the general structural evolution.

The dating of tectonic events producing different sets of faults is based on several criteria. Synsedimentary faults would determine directly the age of deformation, but they are scarce in our study area. In the absence of 


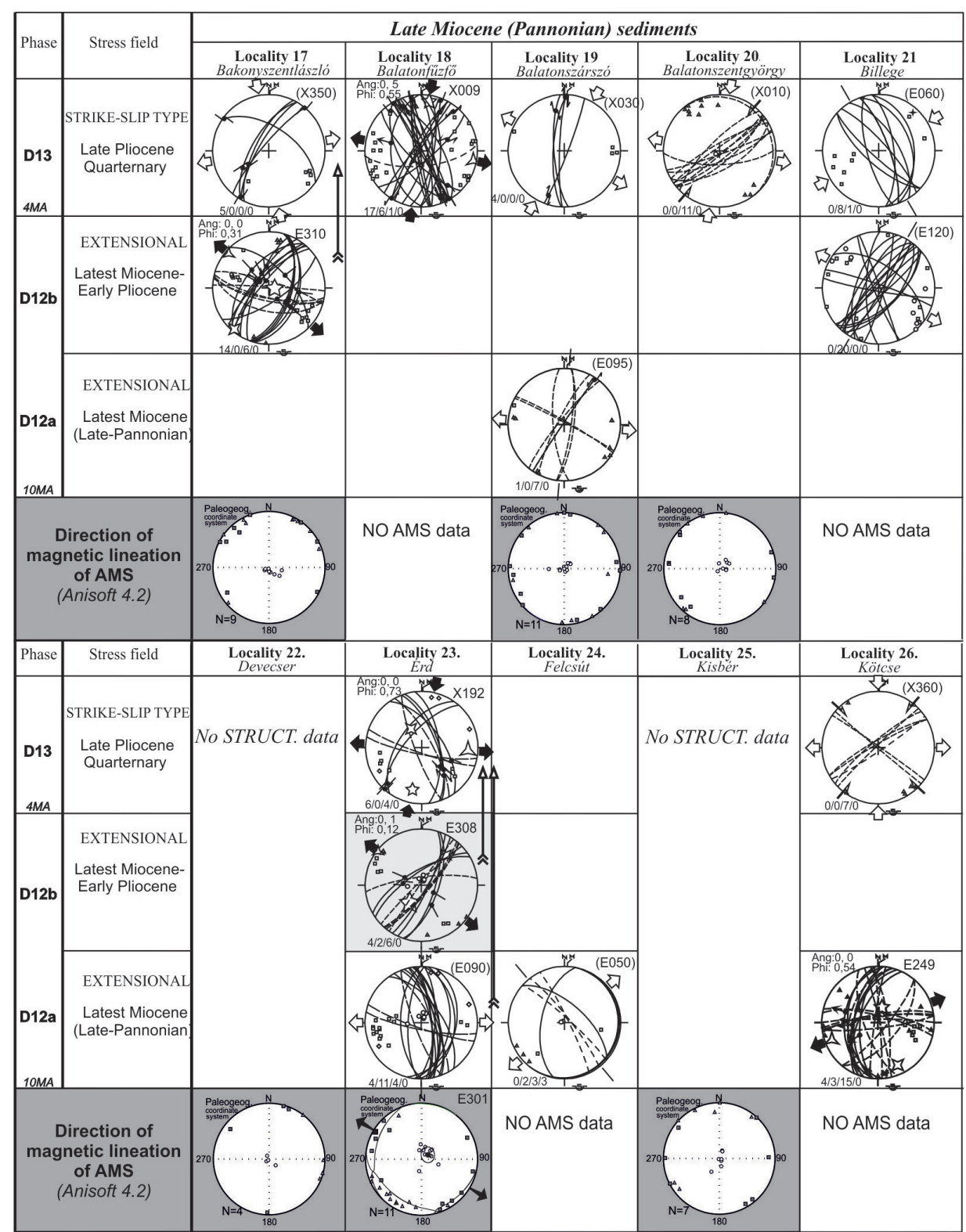

Fig. 7

Calculated principal stress axesfor deformation phases and direction of magnetic lineation of AMS in Late Miocene (Pannonian) sediments. Dark grey color denotes the AMS stereograms, light grey color shows the suggested structural stress field 


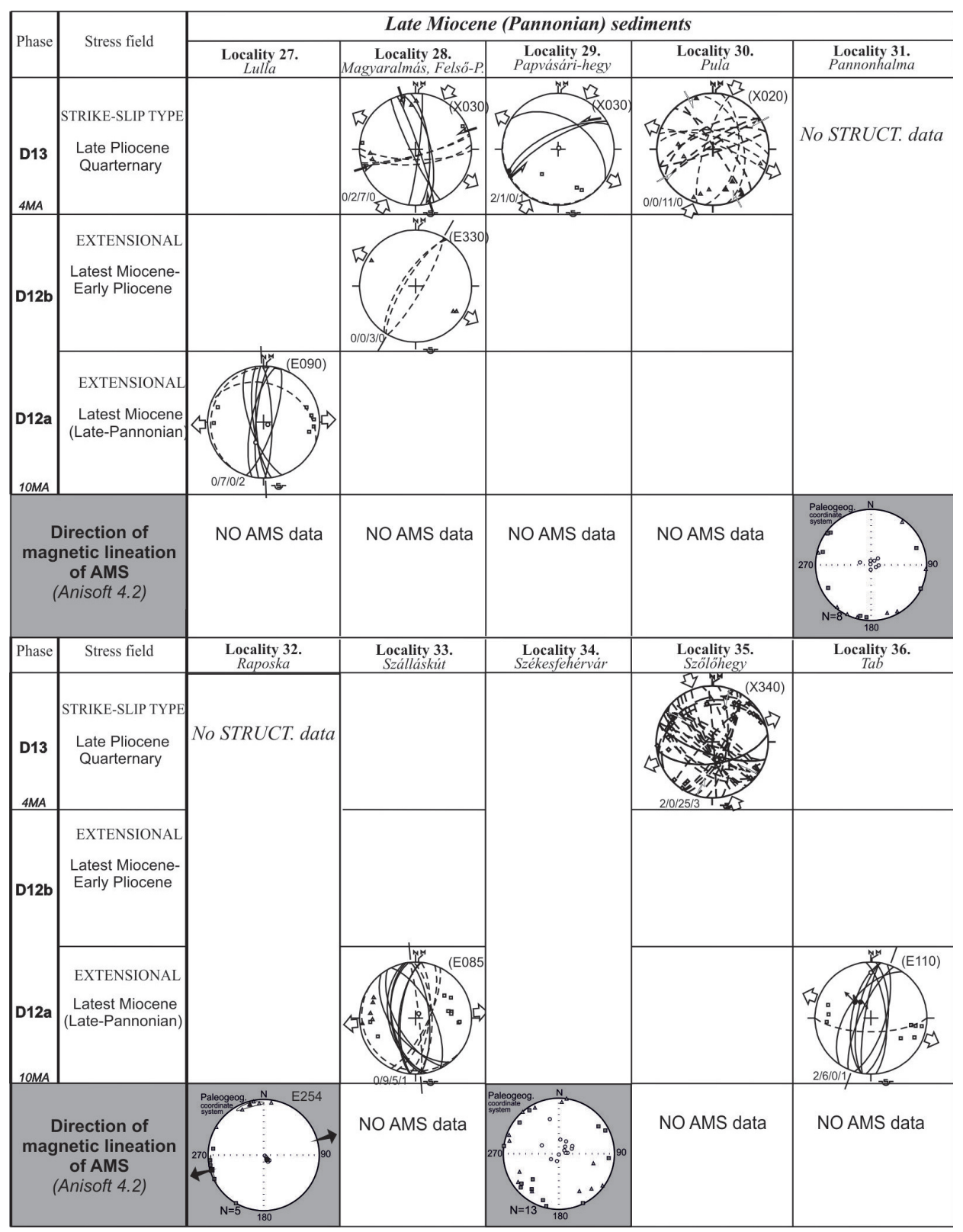

Fig. 7 cont. 


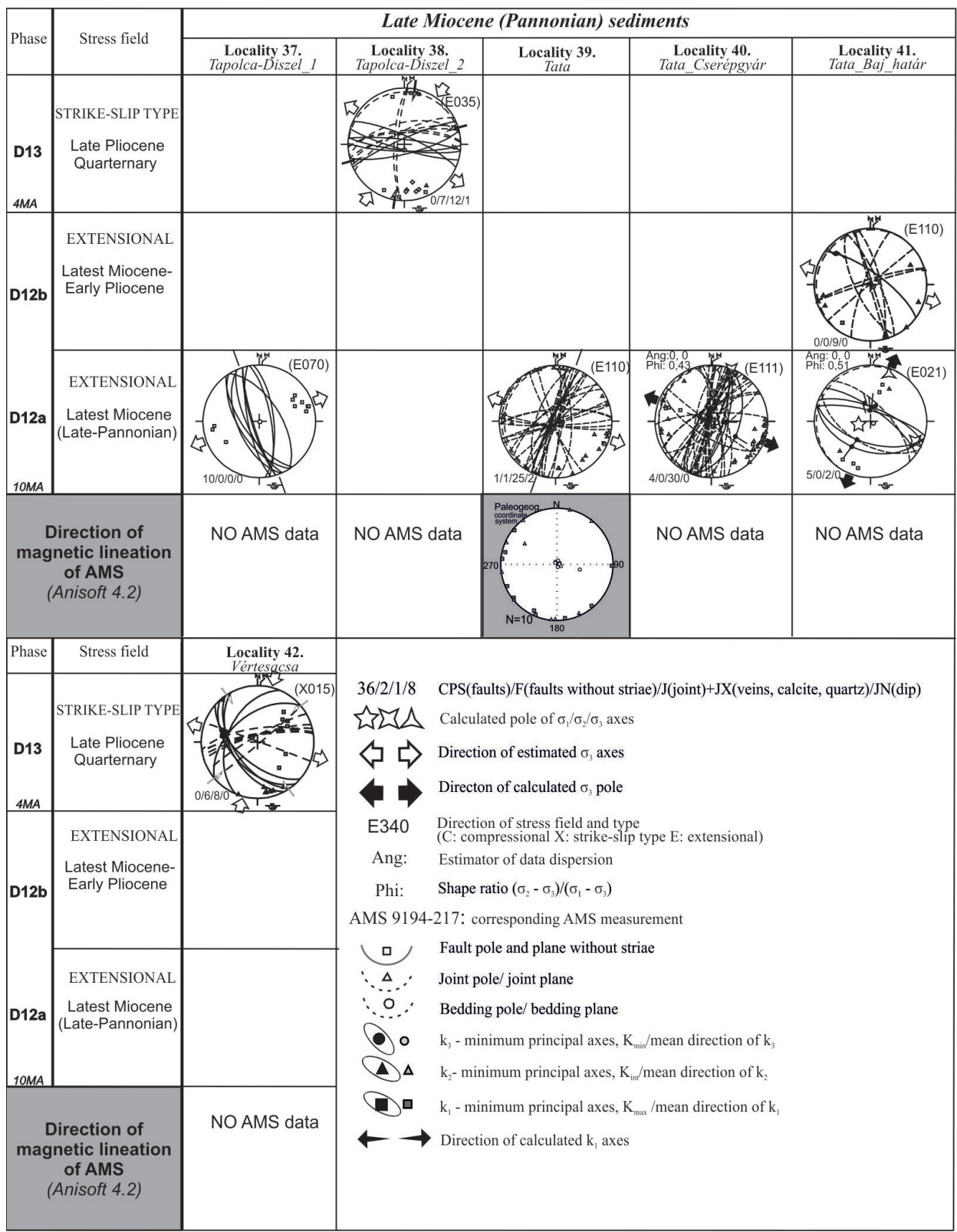

Fig. 7 cont. 
synsedimentary faults, the age of the deformed rocks, relative age of fault striations and cross-cutting relations did help to determine the relative succession of the deformation phases.

The data are commonly collected from tilted sequences. By applying tilt correction the age of deformation can be classified either as pre-, syn- or post-tilt. In case the deformation occurs before tilting the data must be completely corrected by restoring the bed to its original horizontal position. In the case of syn-tilt fractures, backtilting is only partial and does not reach subhorizontal bedding position. Finally, for post-tilt fractures no tilt correction is needed. Thus tilting gives a good relative chronology of events.

It is also possible to establish the relative order of fractures if reactivation (new slip event) occurred along the surface of previously formed faults. This criterion can be recognized by striae which overprint each other on the same fault plane. However the reactivations could also be suggested by analyzing the stereographic pictures of fractures. In these cases the striae appear on a plane which is not characteristic for the given fault type. For example, it is frequent that horizontal striae are recognized on moderately dipping planes: this we interpret as strikeslip or slightly oblique striae appear on the plane of former normal faults which had a dip value of $50^{\circ}-65^{\circ}$.

\section{Results}

\section{Magnetic susceptibility anisotropy}

In the studied sediments the magnetic susceptibilities were quite weak (in most cases $200-450 \times 10^{-6}$ SI in the Eocene-Oligocene and 97-218 $\times 10^{-6}$ SI in the Miocene rocks; Table 1). Thus, it is probable that paramagnetic minerals substantially contribute to the bulk susceptibility. Exceptions are localities 14, 17, 22,25 , and 39 where higher bulk susceptibility suggests higher ferromagnetic content. The average anisotropy degrees $(\mathrm{P})$ vary from 6.3 to $15.4 \%$ in the Eocene and Oligocene and from 1.1 to $6.7 \%$ in the Miocene sediments (Table 1). In both groups, foliation is the dominant feature of the AMS fabric (higher in Eocene and Oligocene than in Miocene sediments; Table 1), i.e. susceptibility ellipsoids are oblate, which is the result of deposition/compaction. As a rule the magnetic foliation plane becomes sub-horizontal after tilt correction, which indicates that tectonic deformation must have been weak.

Magnetic lineations are weak at sample level; maximum and intermediate directions are quite often intermixed. The result is extremely low lineation degree at locality level, which is typical for Miocene sediments (Table 1). Concerning the Paleogene localities, three patterns can be distinguished. In the first case (example is Fig. 3/a) the three principal susceptibility axes are well grouped. In the second case the maxima and the intermediate axes are separated but the confidence intervals are rather extended (example is Fig. 3/b). Finally, in the third case the maximum and intermediate susceptibility axes are intermixed, i.e. no magnetic 


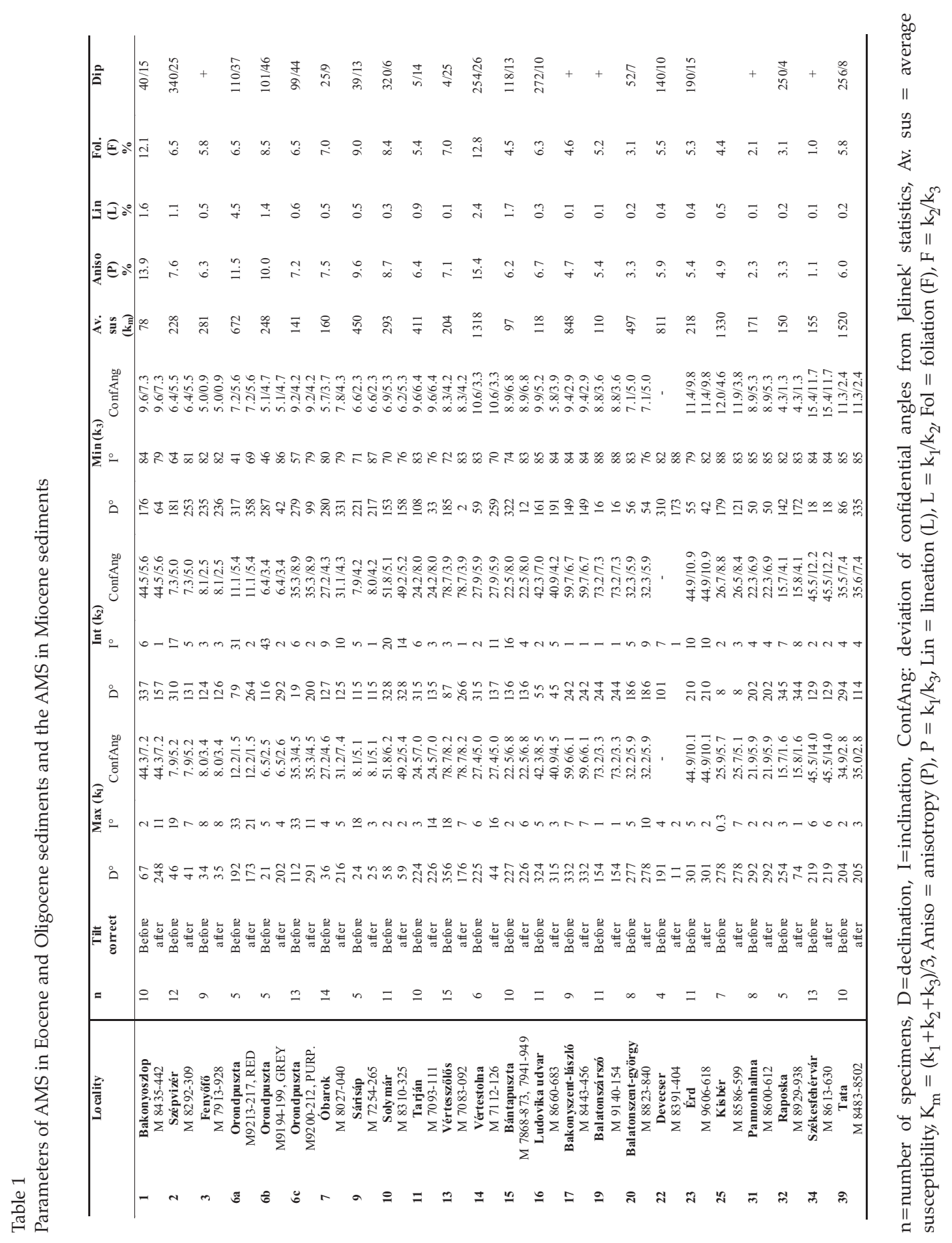


lineation could be defined at locality level (example is Fig. 3/c). To the first group belong Localities 2, 3, 6, 9, and 15/a, to the second Localities 1, 7, 10, 11, 14, 16, and 23 , and to the third most of the Pannonian localities, that is $13,17,19,20,22,25,31$, 32,34 , and 39. Apart from these clearly classifiable groups, localities 13 and 6 require further examination. On the basis of mechanical evaluation, Locality 13 belongs to the third group. However, it is possible to recognize two populations within the locality, since the maxima cluster at two places, permitting recognizing a NE-SW (13/a) and NW-SE (13/b) oriented lineation, respectively. Two groups of AMS lineations can also be distinguished at locality 6. Here the first group is clearly related to the two lower horizons sampled (red bauxitic clay and grey clay), and the second to the uppermost horizon of purple clay.

\section{Outcrop-scale tectonic observations}

Most of the measured faults are characterized by well-developed slickensides, which allow precise definition of the fault kinematics in Eocene, Oligocene and Miocene sediments. The regional structural development of the studied localities was based on Fodor et al. (1999), Márton and Fodor (2003), Fodor (2008, 2010), (Fig. 4), and was compared to other, more localized work such as Sasvári et al. (2007) and Kiss and Fodor (2007). The short summary of phases by Fodor $(2008,2010)$ is in the Appendix of the present paper. According to these studies, 13 phases of deformation can be distinguished from Jurassic to present. The first five phases are older, while phases D6-13 are of Cenozoic age. Concerning the Cenozoic deformations, only two investigated localities fall in the time span of phase D6 (Eocene to earliest Oligocene), but the sites do not exhibit this deformation (Figs 4 and 5).

In our analysis the oldest deformation phase could be examined in Oligocene Locality 6 (Figs 4 and 5), where normal faults with clear synsedimentary character were observed, as demonstrated by Benkô et al. (2005) and Fodor (2008). The deformation phase is characterized by NNE-SSW extension, which is parallel to the minimum stress axis of the D7 phase of Fodor (2010; Fig. 4). The age of synsedimentary deformation is late Early Oligocene, ca. 31-29 Ma. At all other localities investigated by combined magnetic and fault-slip methods, we could not demonstrate the synsedimentary character of fractures; thus the exact age (Oligocene versus early Miocene) cannot be unambiguously determined. According to Fodor (2010) the separation of the D7 and D8 phases would be possible if the synsedimentary character of deformation D7 could have been proven. In the absence of clear synsedimentary character, the D7 and D8 phases (of Fodor 2008, 2010) cannot be unambiguously separated, so we treated these data as belonging to one - although probably combined - phase. However, to keep our nomenclature close to earlier work, we designate this phase as D7-D8.

The first (D7-D8) deformation phase, both in the Eocene and Oligocene sediments, is characterized by W-E to NW-SE compression and N-S to NE-SW 
tension (Fig. 5), with conjugate strike-slip faults: sinistral and dextral strike-slip faults trend N-S to NW-SE and E-W to NE-SW, respectively. Normal faults trend WNW-ESE, characterizing NNE-SSW extension in Localities 2 and 10. Smallscale compressional structures (Locality 5) with NE-SW strike were also identified by Kiss et al. (2001) and Márton and Fodor (2003). Sasvári et al. (2007) measured a similar strike-slip stress field as well with NNE-SSW extension and WNW-ESE compression (Fig. 4).

The second deformation phase (D9) was characterized by NE-SW tension (Figs 4 and 5). Normal faults and joints trend NW-SE to NNW-SSE (Localities 1, 2, 3, 7, $8,9,10,11$, and 12), oblique-sinistral faults trend N-S in Eocene and Oligocene Localities 2 and 12 (Fig. 5). In the Lower Miocene sediments (OttnangianKarpatian) the NW-SE maximal and NE-SW minimal principal stresses characterize conjugate strike-slip faults (Fig. 6). The left-lateral strike-slip faults trend N-S to NNW-SSE, the right-lateral strike-slip faults trend E-W. The strikeslip faults represent the oldest phase in this locality because they were formed before a local tilting event, while the younger phase postdates tilting. The observed strike-slip character is a local feature, and is connected to closely located map-scale strike-slip faults (Mészáros 1983; Balla and Dudko 1989; Sasvári et al. 2007). A similar local stress field occurs in other Pannonian Basin localities (Fodor et al. 1999). The pre-tilt nature of this stress field could have occurred at an early stage of the D9 phase, just after or partly coeval to sedimentation, probably in the Karpatian to early Badenian.

The superposition of the striations on fault surfaces clearly indicates the change of the stress field in Locality 6, from NE-SW tension to W-E tensional stress field in the Middle Miocene, around 15-14 Ma. The normal faults of this phase trend $\mathrm{N}-\mathrm{S}$ in Localities 4, 10, and 13 (Fig. 5), so they most probably belong to the D10 phase. However, local time constraints are lacking, so the classification into D9 or D10 stress fields is based solely on stress axis direction and comparison to more regional data sets (e.g. Fodor et al. 1999; Fig. 4) but does not occur in all analyses (Sasvári et al. 2007). In the Middle Miocene sediments (Locality 15/a; Fig. 6) only two pieces of N-S trending joints seem to fit to this phase. Supposing their purely extensional origin, the E-W extension of the D10 phase could be estimated using the Anderson (1951) method.

The most pronounced structural elements of the next, D11 deformation phase, are conjugate sets of strike-slip faults (Locality 3; Fig. 5). The left and right lateral strike slips trend NNE-SSW and NW-SE, respectively. The stress field is characterized by NNW-SSE compression and ENE-WSW tension (Fig. 4). ENEWSW tension was calculated for Locality 8 (Fig. 5), but the presence of oblique dextral strike-slip faults may suggest its classification to the D11 instead of the D10 phase. The strike-slip-type stress field characterizes the map-scale dextral strikeslip faults, which are typical for the Bakony Mts. in the Middle-Late Miocene (Mészáros 1983; Kiss and Fodor 2007; Sasvári et al. 2007). 
The following phase was an extensional deformation (D12), which affected all formations including the late Miocene (Pannonian) strata. The direction of the minimal stress axes showed a larger dispersal in the earlier works of Fodor et al. (1999) and Fodor $(2008,2010)$ ranging from E-W to SE-NW (Fig. 4). With our detailed analysis we think that this variations are not random but can be systematic; thus we separated the D12 phase into D12a and D12b phases (Figs 5, 6, and 7). The D12a phase is characterized by E-W to WNW-ESE tension. The most typical structural elements of this deformational sub-phase were the NNWSSE, N-S to NNE-SSW-trending normal faults and joints. The D12b sub-phase is characterized by NW-SW tension (Figs 5, 6, and 7). The typical structural elements were the NNE-SSW to NE-SW-trending normal faults and joints. Although these two phases can be found in Eocene (Fig. 4), Oligocene (Fig. 5), and Middle Miocene (Fig. 6) sediments, the separation of phases in individual sites show uncertainty: the number of phases and the relative chronology of stress fields were supported by observations of several phases in Pannonian Localities $17,19,21$, and 23.

The youngest (D13) strike-slip phase is marked by NNE-SSW compression and WNW-ESE tension. Conjugate sets of strike-slip faults were observed: the dextral faults trend NNW-SSE, the sinistral ones NE-SW (Fig. 7). This phase appeared mostly in the Late Miocene sediments (Fig. 7). It could be well correlated with the D13 phase of Fodor (2008, 2010; Fig. 4).

The relative timing of phases D12a, D12b, and D13 can be determined by superimposed striations and the reactivated nature of faults. The best locality is 23, where three phases were observed (Fig. 7). The dextral striae of the D13 are slightly oblique and occur on steep but not sub-vertical planes: both can indicate reactivation. The D13 dextral striae are on the plane of N-S trending faults of the first phase (D12a), which means that the oblique dextral striae are younger than the steep N-S planes themselves. The gently plunging sinistral striae (D13) are on the NE-SW-trending, moderately dipping planes of former normal faults, which means that the sinistral striae are younger than, and reactivated, the older normal faults (D12b).

Another example for reactivation is Locality 17. Two phases are distinguished: NW-SE extension (D12b) and a strike-slip-type phase with N-S compression and ENE-WSW extension (D13). Left and right-lateral strike-slips trend NE-SW and NW-SE, respectively. For both fault sets, the strike-slip striae appear on steeplymoderately dipping planes of the older normal faults, which indicate reactivation of tensional normal faults by a younger stress field.

Despite the relatively clear relative chronology, the "absolute" timing of these phases is not clear. While the D13 phase is considered as the neotectonic phase, it may have an age of late (?) Pliocene-Quaternary (ca. 4-0 Ma), while D12a and $\mathrm{D} 12 \mathrm{~b}$ could have occurred during the Late Miocene (Pannonian) to early Pliocene, ca. $10-4 \mathrm{Ma}$. 
Locality 41 is an exception with respect to the D12a, D12b and D13 phases where NNE-SSW tension occurs. We have no clear explanation for this local deformation. One explanation could be that the fractures are parallel to the general direction of the extension of D12a phase. This could be the case if the stress axes $\sigma_{2}$ and $\sigma_{3}$ could switch; such stress axis permutation has been reported in other extensional terrains (Angelier and Bergerat 1983).

\section{Discussion}

\section{Comparison of AMS and paleostress data}

Eocene and Oligocene sediments

From the microtectonic measurements one or more deformation phases were calculated or estimated. For Localities 2, 3, 5, 6, 9, 10, and 14, the oldest phase observed can be identified as belonging to D7-D8, while for Localities 1, 7, 8, 11, and 12 it is D9. When the minimum stress axes of the oldest phase appearing at the respective localities are compared to AMS lineations (Fig. 5) they show close correlations (Fig. 8). Exceptions are Localities 2 and 10 (Fig. 5) where the AMS lineations are parallel with the second phase of the local brittle deformation history. However, the fractures of the first phase are only represented by joints, so their interpretation in terms of stress is not unequivocal. Therefore the AMS lineations of the above groups are compared deliberately with the extensional direction of D9. The data set could be separated into two groups (Fig. 9). In one group AMS axis $\mathrm{k}_{1}$ is correlated with the NNE-SSW extensional direction of the D7-D8 strike-slip phase (Figs 4, 8 and 9; Localities 3, 6, 9, and 14), in the second one with the NE-SW $\left(\sigma_{3}\right)$ direction of the D9 extensional phase (Figs 4, 8 and 9; Localities 1, 2, 7, 10, and 11). The average angular difference between the direction of AMS lineation and the extensional stress axes of D7-D8 is $8^{\circ}$; for phase D9 it is only $2^{\circ}$ (Fig. 9; Table 2). Thus it is reasonable to conclude that directional similarity reflects true structural connection and the two deformation markers are interconnected and characterize the same deformation phase.

The average angular difference between the minimum stress axes of the two sets of data (phases D7-D8 and D9) is ca. $15-20^{\circ}$, in the same range as the observed difference between the paleomagnetic directions of two rotation phases (Márton and Fodor 2003), suggesting that the change in the orientation of the fault-related extension is mostly apparent, i.e. basically due to the general CCW rotation of the Transdanubian Range (Márton and Fodor 2003).

Despite the general agreement between the minimum stress axes and AMS lineations, there are two cases with a slightly different scenario. For Locality 14 the AMS lineation is quite far $\left(26^{\circ}\right)$ from its structural data (Fig. 9; Table 2), and very close to Locality 7. While data set 7 is of extensional type, data set 14 is strike-slip type. This agrees well with our other paleostress data (Fig. 5) and supports the hypothesis of a separate extensional and a strike-slip phase. The other option is 
that the AMS lineation for Locality 14 indicates another stress field, which could not be measured by the structural method. In the case of Locality 13 the interpretation of the AMS fabric (Fig. 10) is not unique and the structural measurements also indicated two phases. The older phase (D10) is a W-E extensional phase with no manifestation in the AMS fabric, but the younger one (D12b) is parallel with the $13 / b$ lineation direction. A possible interesting explanation for this result is that the effect of a younger structural event appears on the AMS fabric. Concerning the NE-SW direction of AMS lineation, it is not visible in the local structural data, but it is parallel to the extensional direction of the D9 phase: in this scenario, the AMS lineation would indicate the same early phase as in other localities (Fig. 5; Localities 1, 2, 6, 7, and 10), but in site 13, the structural record would not show this D9 phase.

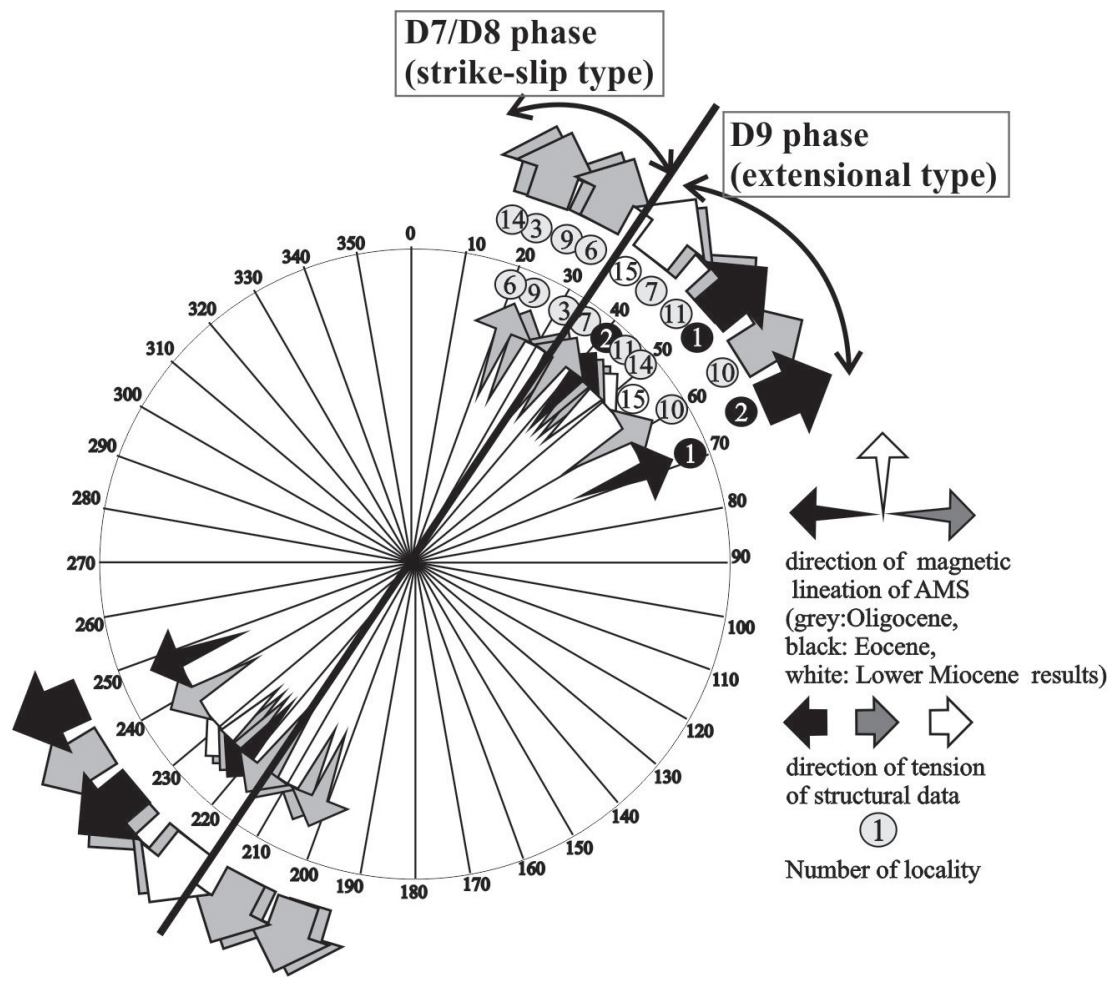

Fig. 8

The correspondence between the orientations of calculated extension and magnetic lineation in Eocene and Oligocene sediments. In one group the AMS axis $k_{1}$ is parallel with the NNE-SSW extensional direction of the D7-D8 strike-slip phase. The second one is aligned with the NE-SW $\left(\sigma_{3}\right)$ direction of the D9 extensional phase 
At locality 6 (Orondpuszta) we carried out measurements on samples from three beds of different color and composition: the oldest being red bauxitic clay (Fig. 11,6/a), the next a grey marlstone (Fig. 11,6/b), the third a purple marlstone (Fig. 11,6/c). The mean lineation for the two older beds is somewhat different, but not significantly. The oldest extensional axis of the fault-slip data is slightly better aligned with the lineation of the grey layer than the red one. We already presented the arguments that the faults are related to a synsedimentary deformation of late Early Oligocene age (Benkô et al. 2005), so they can be classified to Phase D7 (Fodor 2008). The direction of the AMS lineation for the third bed is parallel to the extension of a younger phase (D12b).

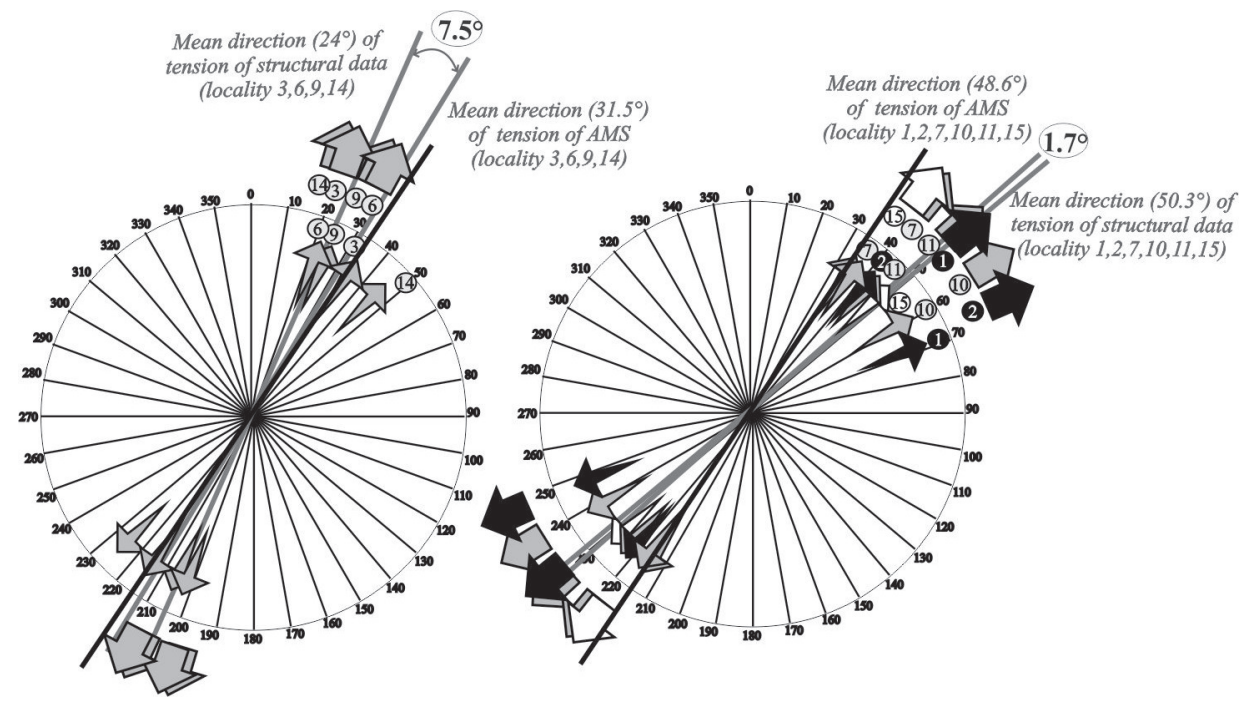

Fig. 9

The orientations of calculated extension and magnetic lineation from Fig. 8 attributed to different phases; angular difference between mean orientations of the parameters. The averaged angular difference between the direction of AMS lineation and the extensional stress axes of D7-D8 is $8^{\circ}$, for phase D9 it is only $2^{\circ}$

It is to be noted that at several localities $(1,4,7,8,11,12$, and 13), neither the AMS nor the fault-slip data set record the oldest possible deformation phase, which occurred just after the deposition of the studied sediments. In the Oligocene sediments, the oldest possible phase would be the D7 synsedimentary midOligocene phase or the post-sedimentary latest Oligocene-Early Miocene D8 phase, while in the above localities only the D9 phase occurs, which post-dates sedimentation by 5-12 Ma. This most likely indicates an uneven occurrence and/or preservation of fractures and the AMS pattern; i.e. the D7 and D8 phases have not uniformly affected the whole of the Transdanubian Range. 
Table 2

Deviation of direction of average lineation and tension of structural data

\begin{tabular}{ccccc}
\hline Localities & $\begin{array}{c}\text { Direction of } \\
\text { lineation of } \\
\text { AMS }\left({ }^{\circ}\right)\end{array}$ & $\begin{array}{c}\text { Direction of } \\
\text { tension of } \\
\text { structural data }\left({ }^{\circ}\right)\end{array}$ & $\begin{array}{c}\text { Deviation } \\
\left({ }^{\circ}\right)\end{array}$ & Phases \\
\hline 1 & $68-248$ & $52-232$ & 16 & D9 extension phase \\
2 & $41-221$ & $60-240$ & 19 & D9 extension phase \\
3 & $34-214$ & $21-201$ & 13 & D7-8 strike-slip \\
6 & $22-202$ & $28-208$ & 6 & D7-8 strike-slip \\
7 & $36-216$ & $41-221$ & 5 & D9 extension phase \\
9 & $25-205$ & $28-208$ & 3 & D7-8 strike slip \\
10 & $59-239$ & $60-240$ & 1 & D9 extension phase \\
11 & $43-223$ & $50-230$ & 7 & D9 extension phase \\
14 & $45-225$ & $19-199$ & 26 & D7-8 strike slip \\
15 & $46-226$ & $39-219$ & 7 & D9 extension phase \\
\hline
\end{tabular}

In summary, the majority of the localities exhibit a close correlation between the directions of the AMS lineations and extensional stress axes, which proves that the magnetic lineation is of deformational origin. Moreover, the magnetic fabric mainly, but not exclusively, reflects the first deformation phase, which is recorded in the rock. As we discussed earlier, this is not necessarily the oldest possible synsedimentary deformation but the first which left traces in the sediments. This conclusion was earlier observed by several authors working with young clay-rich sediments (Alfonsi 1997; Mattei et al. 1997; Cifelli et al. 2004; Soto et al. 2008; Márton et al. 2011). It is possible that the first step in a given deformation phase, a ductile episode is recorded in the AMS fabric, while the closely following second step, the brittle deformation in the mesotectonic markers. Alternatively, the ductile deformation marks the grain size deformation picture, while fractures reflect deformation pattern at outcrop scale.

Lower and Middle Miocene (Ottnangian-Badenian) sediments

The susceptibility axes are well grouped and show magnetic fabric lineation in Locality 15a, and are parallel to the direction of extension (Fig. 6). The wellgrouped direction of lineation is aligned with the extensional axis of the D9 stress field of Karpatian-Early Badenian age. Although this phase is generally extensional, local strike-slip-type stress state is present, particularly close to site 15, where several important map-scale strike-slip faults crosscut the Bakony Mts. (Fig. 1; Mészáros 1983; Kókay 1976, 1996; Sasvári et al. 2007). The direction of lineation and the extension is NE-SW, as in several Eocene-Oligocene sites. In Locality 16 the AMS maxima and the intermediate axes are separated but the confidence ellipses are quite large. 


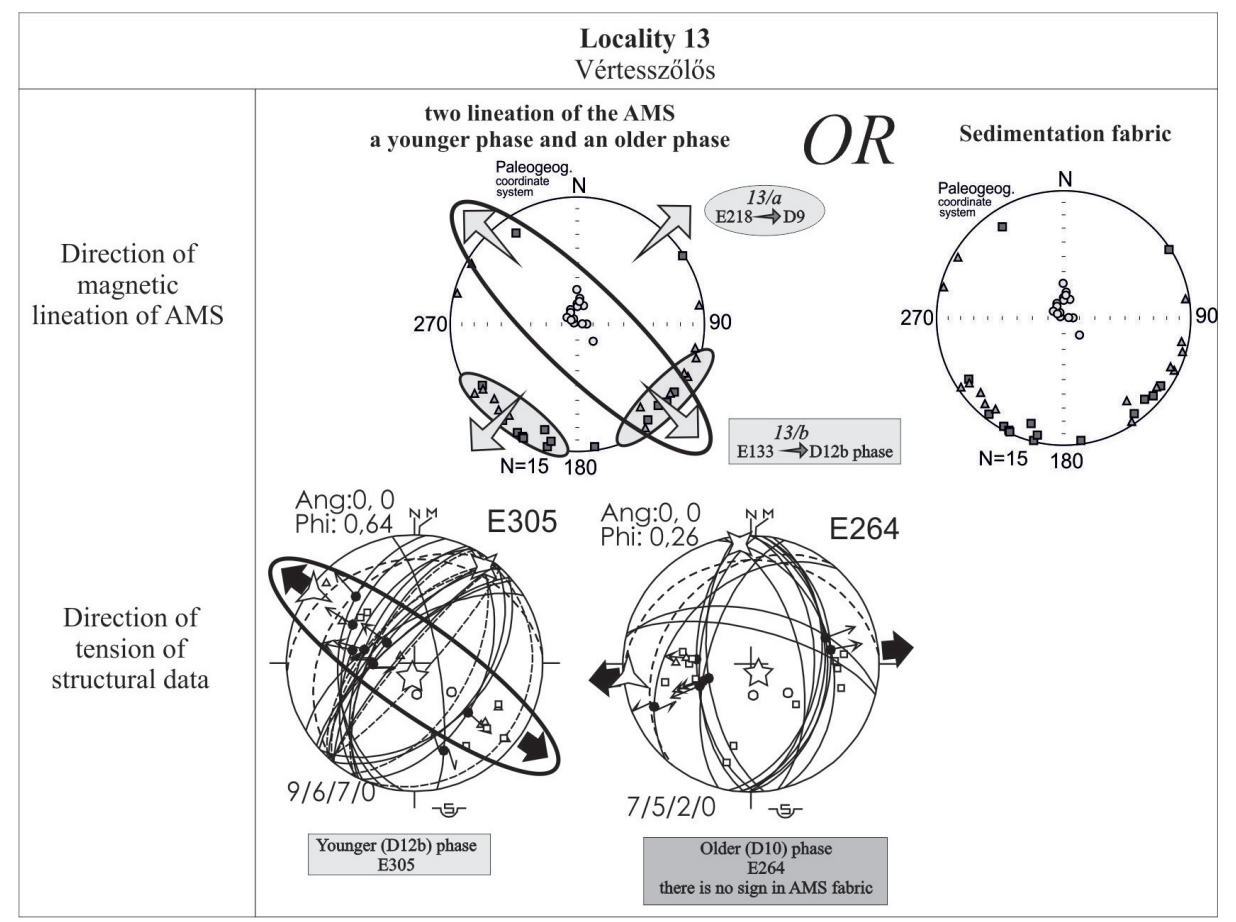

Fig. 10

Possible interpretations of the AMS data from Locality 13 and correlation with the calculated and separated stress fields

Late Miocene (Pannonian) sediments

The magnetic fabrics of Late Miocene sediments studied with both methods are foliated. The maximum and intermediate susceptibility axes are scattered, so they could not be correlated to any tectonic phase. An exception is Locality 23, with a weakly developed lineation superimposed on the dominantly foliated AMS fabric. In this case the lineation can be interpreted as due to water flow, since the minima show smeared distribution toward the maxima (Fig. 2/b, 7). However, the influence of tectonic deformation on the AMS fabric cannot be excluded, since the lineation is sub-parallel to the extensional axis of the D12b faulting phase (Fig. 7).

There are five other localities, where there were AMS studied without structural analysis (Fig. 7). All except one have only foliated fabric. The exception is Locality 32, with well-defined magnetic lineation which can be due to tectonic deformation. This AMS direction is parallel to the estimated extension (ENEWSW extension) at the Diszel site (Locality 37). Both localities are in the neighborhood of the Tapolca Trough (Fig. 1). Looking at map-scale structures, this direction is perpendicular to the faulted margin of the Tapolca Trough (Thamóné et al. 2012; Fig. 1), so a tectonic (extensional) origin of this AMS is quite probable. 


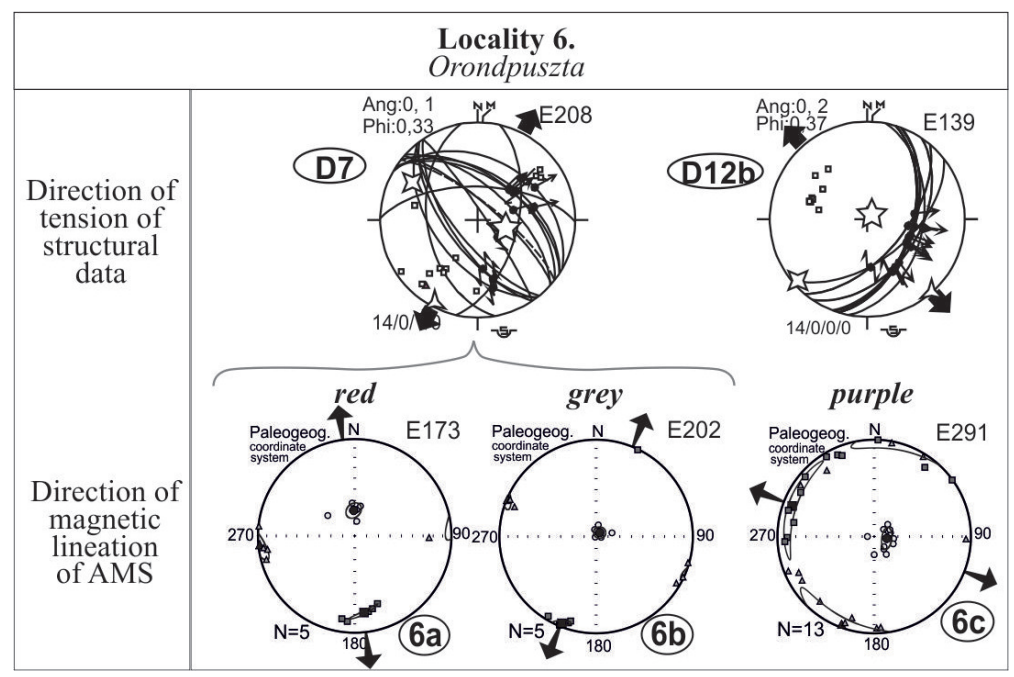

Fig. 11

Calculated principal stress axes for deformation phases and the direction of magnetic lineations of AMS at Locality 6 (Orondpuszta). The structural stereograms show the suggested stress fields. Legend is in Fig. 7

Thus we interpret the AMS texture of Locality 32 as being similar to fracture data of Locality 37. According to the age of sediments at both localities (32 and 37) the direction of AMS was created in the D12a phase.

Comparison of AMS data from Late Miocene and older sediments

The AMS fabric of older sediments is of foliated texture with weak lineation, indicating the tectonic effects of stress fields. The AMS texture of the studied Late Miocene sediments is only based upon sedimentological character, without any tectonically interpretable lineation. This can mean that there was no early tectonic deformation, but rather a somewhat later one, when the deformation of AMS was no longer possible. An alternative interpretation would be that the intensity of the early, closely synsedimentary ductile deformation was very small in late Miocene sediments, not enough to imprint the AMS pattern, while the brittle deformation might have been somewhat stronger. It is to be noted that Late Miocene faulting was not very strong in the studied localities; fault displacements remained modest. The amount of mesoscale faulting was much larger in the Oligocene localities where, in fact, the AMS data depict the ductile aspect of this deformation. 
New elements in the Late Miocene to Quaternary stress field classification and evolution

Since 35 localities were investigated by structural methods, with this considerable number we can now refine the Late Miocene and PlioceneQuaternary structural and stress field evolution, outlined by Fodor et al. (1999), Márton and Fodor (2003), Bada et al. (2010) and Fodor (2010). One Eocene (Locality 2), four Oligocene (Localities 4, 5, 9, and 13) and 15 Late Miocene sites recorded the D12 deformation phase, which can be now separated into D12a and D12b, based mainly on the orientation of $\sigma_{3}$ tensional axes. The D12a phase is characterized by E-W to WNW-ESE extension. The D12b phase is characterized by NW-SW extension. Although the separation of these two phases is tentative, their distinct existence seems to be quite realistic.

The kinematics and fault geometries of the youngest deformation phase (D13) are similar to those inferred for the neotectonic (also present-day) stress field (Fodor et al. 2005; Bada et al. 2010) on the basis of various data sets, including very few outcrop-scale fractures. Our data set extends the number of localities where this neotectonic phase has been recorded by brittle fractures.

Contrast between the ductile and brittle deformation of the Late Miocene sediments in the Transdanubian Range and in the Slovenian and Croatian parts of the South Pannonian Basin

The magnetic fabrics of the Late Miocene sediments in the Transdanubian Range are foliated, in the majority of the cases without lineation, i.e. do not show any sign of ductile deformation. In contrast, joints and faults were observed in the outcrops, which were interpreted in terms of two extensional (10-4 Ma) and a younger strike-slip phase.

In the southern Pannonian Basin the same types of sediments of similar ages lack the markers of brittle deformation, but have well-developed lineations interpreted as being due to shortening or transpressional deformation (Márton et al. 2011).

The explanation may be that the northward-moving and counterclockwise (CCW) rotating Adriatic microplate induced the deformation in the entire Pannonian Basin. However, this motion caused strong shortening (Tomljenović and Csontos 2001), resulting in the ductile deformation of the young clay-rich sediments in the southern Pannonian Basin. The Transdanubian Range was further north from the location of strong contractional deformation and probably had a more rigid pre-Cenozoic basement; therefore its young sediments were not affected by ductile deformation. 


\section{Conclusions}

Based on the study of the magnetic fabrics of clay and marly clay sediments from the Transdanubian Range, central Hungary (22 geographically distributed localities, 233 samples) and the results of structural measurements (35 localities) the following conclusions can be drawn:

1. The Eocene, Oligocene and Lower Miocene sediments show similar characters in AMS fabric with dominant foliation and weak lineation. The directions of AMS lineation are aligned either to the direction of NNE-SSW extension of a strike-slip phase (30-19 Ma) or to a NE-SW direction of an extension phase (19-14 Ma).

2. The magnetic lineation, which is due to ductile deformation, is in the majority of the cases aligned with the direction of the extension of the oldest brittle deformation phase recognized in the studied sediment.

3. The oldest recoded ductile and brittle deformations in a given locality are not always related to the oldest deformation phase that could have affected the sediment. While the absence of the markers of the synsedimentary brittle deformation is not expected for every particular locality, it is an open question as to why strictly synsedimentary deformation at several localities is not reflected in the AMS data.

4. The magnetic fabrics of Late Miocene sediments are foliated without lineation. They exhibit no sign of tectonic (ductile) deformation. Nevertheless, joints and faults, as the sign of the brittle deformation, were observable. We separated two extensional phases between 10-4 Ma: the first one is an E-W to WNW-ESE tension, the second exhibits NW-SW extension. This separation is tentative but would represent a more detailed separation of post-Middle Miocene evolution than earlier studies. Furthermore we identified the youngest strike-slip phase with an E-W tension and a N-S compression. This youngest (neotectonic) deformation phase agrees well with the existing few measurements in Pannonian Basin but extends the number of localities with neotectonic fractures.

5. The acquisition of the AMS lineation does not seem to post-date more than ca. $10 \mathrm{Ma}$ the time of sedimentation. In all cases except for two localities, where the markers of the brittle deformation are weak, the AMS lineation reliably reflects the locally oldest brittle deformation. Thus the two methods reliably complete each other: any of them can be used for determination of the direction of extension; AMS measurements are good for sites where the outcrop-scale markers of brittle deformation are lacking or were not studied.

6. The results of the present study from the Late Miocene sediments of the Transdanubian Range differ significantly from those obtained earlier for clay-rich sediments of similar ages from the Slovenian and Croatian parts of the southern Pannonian Basin. In the latter area well-developed lineation due to ductile deformation was observed, but markers of brittle deformation were rare. Northward moving and CCW-rotating Adria can explain the strong compression, which resulted in the ductile deformation of the clay-rich sediments in the 
southern Pannonian Basin. The distance of the Transdanubian Range was larger from moving Adria; therefore its young sediments were not affected by ductile deformation.

\section{Acknowledgements}

This work was financially supported by the Hungarian Scientific Research Programs (OTKA), Grant No K 68171, 81530. The manuscript was improved by the valuable comments of two reviewers, Ágoston Sasvári and an anonymous one; their help is acknowledged here.

\section{References}

Alfonsi, L. 1997: Paleomagnetic and anisotropy of magnetic susceptibility (AMS) analyses of the PlioPleistocene extensional Todi-basin (Central Italy). - Annali Di Geofisica, 40/6, pp. 1535-1549.

Anderson, E.M. 1951: The dynamics of faulting. - Oliver and Boyd, Edinburgh, 206 p.

Angelier, J., S. Manoussis 1980: Classification automatique et distinction des phases superposées en tectonique de failles. - C. R. Acad. Sci. Paris 290, série D, pp. 651-654.

Angelier, J., F. Bergerat 1983: Systemes de contrainte et extension intracontinentale. - Bulletin Centres Rech. Exploration-Production Elf-Aquitaine 7/1, pp. 137-147.

Angelier, J. 1984: Tectonic analysis of fault slip data sets. - Journal of Geophysical Research 8. (B7), pp. 5835-5848.

Angelier, J. 1989: From orientation to magnitudes in palaeostress determination using fault slip data. - Journal of Structural Geology, 11/1-2, pp. 37-50.

Angelier, J. 1990: Inversion of field data in fault tectonics to obtain the regional stress - III. A new rapid direct inversion method by analytical means. - Geophysical Journal International, 103, pp. $363-376$.

Bada, G., P. Szafián, O. Vincze, T. Tóth, L. Fodor, V. Spiess, F. Horváth 2010: Neotektonikai viszonyok a Balaton keleti medencéjében és tágabb környezetében nagyfelbontású szeizmikus mérések alapján (The neotectonic habitat of the eastern part of Lake Balaton and its broader environs: inferences from high-resolution seismic profiling). - Földtani Közlöny, 140/4, pp. 367-390.

Balla, Z., A. Dudko 1989: Large-scale Tertiary strike-slip displacements recorded in the structure of the Transdanubian Range. - Geophys. Trans., 35, pp. 3-64.

Balogh, K., E. Árva-Sós, Z. Pécskay, L. Ravasz-Baranyai 1983: K/Ar dating of post-Sarmatian alkali basaltic rocks in Hungary. - Acta Mineralogica-Petrologica Segediensis, 28, pp. 75-94.

Báldi, T. 1986: Mid-Tertiary Stratigraphy and Paleogeographic Evolution of Hungary. - Akadémiai Kiadó, Budapest, 293 p.

Benkő, K., L. Fodor, E. Márton 2005: Structural and paleomagnetic analysis of Miocene rocks in Northern Transdanubia. - Geolines, 19, pp. 22-24.

Bordás, R. 1992: Magnetic fabric and strain in Miocene volcanics in the southern margin of the Bükk Mountains, Hungary. - Physics of the Earth and Planetary Interiors, 70, pp. 205-213.

Borradaile, G.J., M. Jackson 2010: Structural geology, petrofabrics and magnetic fabrics (AMS, AARM, AIRM). - Journal of Structural Geology, 32, pp. 1519-1551.

Cifelli, F., F. Rossetti, M. Mattei, A.M. Hirt, R.L. Tortorici 2004: An AMS, structural and paleomagnetic study of quaternary deformation in eastern Sicily. - Journal of Structural Geology, 26, pp. 29-46.

Chadima, M., V. Jelínek 2008: Anisoft 4.2. - Anisotropy data-browser. Contributions to Geophysics and Geodesy, 38, special issue, $41 \mathrm{p}$.

Dudich, E., G. Kopek 1980: A Bakony és környéke Eocén ősföldrajzának vázlata (Outlines of the Eocene Paleogeography of the Bakony Mountains, Transdanubia, Hungary). - Földtani Közlöny, 110, pp. 417-431. 
Dudko, A., G. Bence, I. Selmeci 1992: The tectonic origin of Miocene basins on the south-western edge of the Transdanubian Central Range. - Ann. Rep. Hung. Geol. Surv. 1990, pp. 107-124.

Fodor, L. 2008: Structural geology. - In: Budai T., L. Fodor (Eds): Geology of the Vértes Hills. Explanatory book to the Geological Map of the Vértes Hills (1:50000). — Geological Institute of Hungary, Budapest, pp. 145-202, 282-300.

Fodor, L.I. 2010: Mesozoic-Cenozoic stress fields and fault patterns in the northwestern part of the Pannonian Basin - methodology and structural analysis. - Doctoral work for the Hungarian Academy of Sciences, 129 p., 7 appendices.

Fodor, L., M. Kázmér, Á. Magyari, A. Fogarasi 1992: Gravity flow dominated sedimentation on the Buda Paleoslope (Hungary). Record of Late Eocene continental escape of the Bakony Unit. Geol. Rundsh., 82, pp. 695-716.

Fodor, L., L. Csontos, G. Bada, I. Győrfi, L. Benkovics 1999: Tertiary tectonic evolution of the Pannonian basin system and neighbouring orogens: a new syntheses of paleostress data. - In: Durand, B., L. Jolivet, F. Horváth, M. Séranne (Eds): The Mediterranean Basins: Tertiary Extension within the Alpine Orogen. - Geol. Soc. Spec. Publ., vol. 156, pp. 295-334.

Fodor, L., G. Bada, G. Csillag, E. Horváth, Zs. Ruszkiczay-Rüdiger, K. Palotás, F. Síkhegyi, G. Timár, S. Cloetingh, F. Horváth 2005: An outline of neotectonic structures and morphotectonics of the western and central Pannonian basin. - Tectonophysics, 410, pp. 15-41.

Fülöp, J., A. Rónai, G. Hámor, E. Nagy, G. Császár, Á. Jámbor, R. Hetényei, M. Deák, P. Gyarmati 1984: Geological map of Hungary, 1:500 000. - Geol. Inst. Hung., Budapest.

Gyalog, L., G. Császár (Eds): 1982: Geological map of the Bakony Mts., 1:50 000. - Geol. Inst. of Hungary, Budapest.

Haas, J., S. Kovács, L. Krystyn, R. Lein 1995: Significance of Late Permian-Triassic facies zones in terrane reconstructions in the Alpine-North Pannonian domain. - Tectonophysics, 242, pp. 19 40.

Harangi, Sz., O. Vaselli, S. Tonarini, Cs. Szabó, R. Harangi, N. Coradossi 1995: Petrogenesis of Neogene extension-related alkaline volcanic rocks of the Little Hungarian Plain Volcanic Field (Western Hungary). - Acta Vulcanol., 7, pp. 173-188.

Hirt, A.M., W. Lowrie, W.S. Clendenen, R. Kligfield 1988: The correlation of magnetic anisotropy with strain in the Chelmsford Formation of the Sudbury Basin, Ontario. - Tectonophysics, 145, pp 177-189.

Howell, P., G. Kozyreff, J. Ockendon 2009: Applied Solid Mechanics. - Cambridge University Press.

Hrouda, F. 1987: Mathematical model relationship between the paramagnetic anisotropy and strain in slates. - Tectonophysics, 142, pp. 323-327.

Jámbor, Á. 1980: A Dunántúli-középhegység pannóniai képződményei (Pannonian in the Transdanubian Central Mountains). - Ann. Geol. Inst. Hung. 62, pp. 12-59.

Jelínek, V. 1977: The statistical theory of measuring anisotropy of magnetic susceptibility of rocks and its applications. - Geofyzika, Brno, 88 pp.

Jelínek, V. 1978: Statistical processing of anisotropy of magnetic susceptibility measured on group of specimens and its applications. - Stud. Geophys. Geod., 22, pp. 50-62.

Kázmér, M. 1987: A Lower Cretaceous submarine fan sequence in the Gerecse Mts., Hungary. Annales Universitatis Scientiarum Budapestinensis De Rolando Eötvös Nominatae - Sectio Geologica, 27, pp. 101-116.

Kercsmár, Zs. 2005: A Tatabányai-medence földtani felépítésének és fejlődéstörténetének újabb kutatási eredményei tektono-szedimentológiai és üledékföldtani vizsgálatok alapján (Synsedimentary deformations in the Eocene, Tatabánya Basin, Central Hungary). - PhD értekezés, Eötvös Loránd Tudományegyetem, Öslénytani Tanszék, 175 p.

Kiss, A., B. Gellért, L. Fodor 2001: Structural history of the Porva Basin in the Northern Bakony Mts. (Western Hungary): implications for the Mesozoic and Tertiary tectonic evolution of the Transdanubian Range and Pannonian Basin. - Geologica Carpathica, 52, pp. 183-190. 
Kiss, A., L. Fodor 2007: Miocene dextral transpression along the Csesznek Zone of the northern Bakony Mountains (Transdanubian Range, western Hungary). - Geologica Carpathica, 58/5, pp. $465-475$.

Kissel, C., E. Barrier, C. Laj, T-Q. Lee 1986: Magnetic fabric in "undeformed" marine clays from compressional zones. - Tectonics, 5/5, pp. 769-781.

Kókay, J. 1976: Geomechanical investigation of the southern margin of the Bakony Mts. and the age of the Litér fault line. - Acta Geologica Hungarica, 20, pp. 245-257.

Kókay, J. 1991: Stratigraphic revision of Lower and Middle-Miocene sediments of the Várpalota basin. - In: Lobitzer, H., G. Császár (Eds): Jubiläumsschrift 20 Jahre Geologische Zusammenarbeit Österreich - Ungarn 1. Geol. Survey of Austria, Vienna, and Geol. Inst. of Hungary, Budapest, pp. 101-109.

Kókay, J. 1996: Tectonic review of the Neogene Várpalota Basin. - Földtani Közlöny, 126, pp. 417-446. (In Hungarian.)

Korpás, L. 1981: Oligocene - lower Miocene formations of the Transdanubian Central Mountains. Annals Geol. Inst. Hung., 64, pp. 1-40.

Lee, T., C. Kissel, C. Laj, Ch. Horng, Y. Lue 1990: Magnetic fabric analysis of the Plio-Pleistocene sedimentary formations of the Coastal Range of Taiwan. - Earth and Planetary Science Letters, 98, pp. 23-32.

Magyar, I., D.H. Geary, P. Müller 1999: Paleogeographic evolution of the Late Miocene Lake Pannon in Central Europe. - Palaeogeography, Palaeoclimatology, Palaeoecology, 147, pp. 151-167.

Magyar, I., D. Radivojević, O. Sztanó, R. Synak, K. Ujszászi, M. Pócsik 2013: Progradation of the paleo-Danube shelf margin across the Pannonian Basin during the Late Miocene and Early Pliocene. - Global and Planetary Change, 102, pp. 168-173.

Márton, E., L. Fodor 2003: Tertiary paleomagnetic results and structural analysis from the Transdanubian Range (Hungary): rotational disintegration of the Alcapa unit. - Tectonophysics, 363, pp. 201-224.

Márton, E., B. Tomljenović, D. Pavelić, M. Pethe, R. Avanić, B. Jelen 2011: Magnetic fabric of Late Miocene clay-rich sediments from the southern Pannonian basin. - Int. J. Earth Sci. (Geol. Rundschau), DOI 10.1007/s00531-011-0669-8

Mattei M., L. Sagnotti, C. Faccenna, R. Funiciello 1997: Magnetic fabric of weakly deformed clay-rich sediments in the Italian peninsula: relationship with compressional and extensional tectonics. Tectonophysics, 172, pp. 107-122.

Mészáros, J. 1982: Major horizontal tectonic dislocation as a guide to mineral prospectors in the western Bakony Mountains. - Ann. Rep. Geol. Inst. Hungary from 1980, pp. 517-536.

Mészáros, J. 1983: Structural and economic-geological significance of strike-slip faults in the Bakony Mountains. - Ann. Rep. Geol. Inst. Hungary from 1981, pp. 485-502.

Mindszenty, A., M. Szintai, K. Tóth, F. Szantner, T. Nagy, M. Gellai, G. Baross 1988: Sedimentology and depositional environment of Csabpuszta bauxite (Paleocene/Eocene) in the South Bakony Mts. (Hungary). - Acta Geol. Hung., 31, pp. 339-370.

Nagymarosy, A. 1990: Paleogeographical and paleotectonical outlines of some intracarpathian Paleogene Basins. - Geologica Carpathica, 41/3, pp. 259-274.

Németh, K., U. Martin 1999: Late Miocene paleogeomorphology of the Bakony Balaton Highland Volcanic field (BBHVF), Hungary. - Zeitschrift für Geomorphologie, 43, pp. 417-438.

Pethe, M., E. Márton, P. Márton 2009: AMS lineations and the orientation of stress axes during Early and Middle Miocene in the Transdanubian Range, Hungary. - Abstract Book of the IAGA 11th Scientific Assembly, 111-TUE-P1110-0867

Royden, L.H., F. Horváth (Eds) 1988: The Pannonian basin: A case study in basin evolution. - AAPG Memoir, 45, pp. 1-394.

Sagnotti, L., C. Faccenna, R. Funiciello, M. Mattei 1994: Magnetic fabric and structural setting of PlioPliocene clayey units in an extensional regime: the Tyrrhenian margin of central Italy. - J. Struct. Geol., 16/9, pp. 1243-1257. 
Sasvári, A., A. Kiss, L. Csontos 2007: Paleostress investigation and kinematic analysis along the Telegdi Roth Fault (Bakony Mountains, western Hungary). - Geologica Carpathica, 58/5, pp. $477-486$.

Sipos-Benkő, K., E. Márton, L. Fodor, M. Pethe 2012: An integrated magnetic susceptibility anisotropy (AMS) and structural geology study on Cenozoic clay rich sediments from the Transdanubian Range. - Environmental, Structural and Stratigraphical Evolution of the Western Carpathians, 8th Conference 2012, Abstract Book, p. 44.

Soto, R., A.M. Casas-Sainz, J.J. Villalain, A. Gil-Imaz, G. Fernández-González, P. Del Río, M. Calvo, T. Mochales 2008: Characterizing the Mesozoic extension direction in the northern Iberian plate margin by anisotropy of magnetic susceptibility (AMS). - Journal of the Geological Society, 165, pp. 1007-1018.

Szentgyörgyi, K., Gy. Juhász 1988: Sedimentological characteristics of the Neogene sequences in SW Transdanubia, Hungary. - Acta Geologica Hungarica, 31/3-4, pp. 209-225.

Tari, G. 1991: Multiple Miocene block rotation in the Bakony Mountains, Transdanubian Central Range, Hungary. - Tectonophysics, 199, pp. 93-103.

Tari, G. 1994: Alpine Tectonics of the Pannonian basin. - PhD. Thesis, Rice University, Texas, USA. $501 \mathrm{p}$.

Tari, G., T. Báldi, M. Báldi-Beke 1993: Paleogene retroarc flexural basin beneath the Neogene Pannonian Basin: a geodynamical model. - Tectonophysics, 226, pp. 433-455.

Tarling, D.H., F. Hrouda 1993: The Magnetic Anisotropy of Rocks. - Chapman and Hall, London, 217 p.

Thamóné Bozsó, E., G. Csillag, O. Kákay-Szabó, P. Kónya, E. Király, P.M. Müller 2012: Szél által polírozott pleisztocén kőzetfelszínek vizsgálati eredményei a Dunántúli-középhegységből (Investigation of polished surfaces by wind in the Transdanubian Range in the Pleistoce age). Annual Report of the Geological Institute of Hungary 2010, pp. 41-53.

Telegdi Roth, K. 1927: Spuren einer infraoligozänen Denudation am nordwestlichen Rande des Transdanubishen Mittelgebirges. - Földtani Közlöny, 57, pp. 117-128.

Tomljenović, B., L. Csontos 2001: Neogene-Quaternary structures in the border zone between Alps, Dinarides and Pannonian Basin (Hrvatsko zagorje and Karlovac Basins, Croatia), - Int. J. Earth Sciences (Geol. Rundschau), 90, pp. 560-578.

Uhrin, A., O. Sztanó 2007: Reconstruction of Pliocene fluvial channels flowing to Lake Pannon. Geologica Carpathica, 58/3, pp. 291-300.

Vakarcs, G., P.R. Vail, G. Tari, Gy. Pogácsás, R.E. Mattick, A. Szabó 1994: Third-order Middle MioceneEarly Pliocene depositional sequences in the prograding delta complex of the Pannonian Basin. - Tectonophysics, 240, pp. 81-106.

Wijbrans, J., K. Németh, U. Martin, K. Balogh 2007: ${ }^{40} \mathrm{Ar} /{ }^{39} \mathrm{Ar}$ geochronology of Neogene phreatomagmatic volcanism in the western Pannonian Basin, Hungary. - Journal of Volcanology and Geothermal Research, 164, pp. 193-204.

\section{Appendix}

The structural evolution of the area

The Transdanubian Range (TR) has a complex deformation history in the Neogene; thus detailed modern structural documentation and analysis began relatively late (Mészáros 1982, 1983; Balla and Dudko 1989; Dudko et al. 1992; Fodor et al. 1992; Kiss et al. 2001). Fodor $(2008,2010)$ divided the structural evolution in the Pannonian Basin into 13 deformation phases and determined the stress fields of each these phases. Although the Triassic is of great significance because of the formation of the Vardar-Meliata branch of the Neo-Tethys ocean 
(Haas et al. 1995), only a few fault-slip data are available from this period in Hungary. This is the reason that according to Fodor $(2008,2010)$ the first deformation phase (D1) occurred in the Jurassic-Early Berriasian (172-140 Ma), with NNE-SSW or NE-SW extension. In the TR there were different Cretaceous strata (Kázmér 1987) and a variable geodynamic background (Tari 1994). This makes it possible that in the TR the Early Cretaceous stress field was not homogeneous but of local character. Thus the second stress field (D2) can be characterized by a NW-SE transtensional stress field in the 140-115 Ma time period. The third deformation phase (D3) could have happened in the middle of the Cretaceous (108-86 Ma) marked by a NW-SE compressional stress field. After this folding period the NE-SE compressional and NW-SE extensional stress field (D4) occurred in the Late Cretaceous to Paleocene (83-56 Ma). The D5 phase could have occurred during a similar tome span: Late Cretaceous to EarlyEocene(?) (86?-49 Ma), although the temporal limits of this phase and the reltionship with D4 phase are poorly constrained. Our paper focuses on the period from Middle Eocene to Recent, so the following phases are explained in greater detail.

The Middle to Late Eocene basins were characterized by WNW-ESE to NW-SE oriented compression and perpendicular tension (D6 phase, 49-34 Ma). This phase was defined by numerous synsedimentary structures in the northern TR (Fodor et al. 1992; Kercsmár 2005). Since we did not observe any synsedimentary Eocene deformation, this phase does not appear in our analysis. The late Early to Late Oligocene stress field (D7 phase, 30-23 Ma) was similar to the one in the Eocene, but it could only be separated from the older (D6) and younger phases (D8) when relative chronology was observed or the deformation was synsedimentary. The most typical structures are the strike-slip faults, oblique-slip faults and reverse faults.

In the early Miocene (up to the end of Eggenburgian, ca. $19 \mathrm{Ma}$, using the time scale of Nagymarosy (1990)) WNW-ESE to NW-SE compression and perpendicular tension (strike-slip phase (D8)) was marked as well. The D6-D7D8 phases were very similar to each other. This conclusion is in agreement with Tari et al. (1993) and Fodor et al. (1999) where contractional deformation characterized the Paleogene basin evolution. The basis for the separation into three phases is the presence of synsedimentary structures at different scales from outcrop to basin scale. The major Neogene rifting phase of the Pannonian Basin reactivated most of the inherited structures trending between NW-SE and NESW (D9 phase) (Fodor et al. 1999). The extensional (D9) phase is characterized by NE-SW tension. The phase could have begun 19 Ma years ago (Early Miocene, Ottnangian) and lasted up to the Middle Miocene (15 Ma). This phase is marked by NW-SE-trending normal faults but E-W trending dextral faults could also be important locally. The D10 phase is marked by E-W extension, initiated in the Middle Miocene (Late Badenian) and continued into the Sarmatian ( 13-11.5 $\mathrm{Ma}$ ). The Miocene extensional deformation was interrupted by a strike-slip type 
phase (D11, 12-10 Ma). A particularity of the TR is the presence of WNW-ESEtrending dextral faults (Kókay 1976, 1996; Mészáros 1983; Balla and Dudko 1989; Tari 1991; Kiss et al. 2001; Kiss and Fodor 2007). The Telegdi Roth Line is a known example of right-lateral transpressional deformation (Kókay 1976; Mészáros 1982, 1983; Sasvári et al. 2007).

The D12 phase is marked by E-W to ESE-WNW extension and is classically considered as a post-rift phase in the Pannonian Basin (Royden and Horváth 1988). The interesting features are the N-S to NE-SW oriented normal faults, which were active during the Late Miocene. The present-day stress field (D13 phase, 2-0 Ma) is only poorly constrained in the entire TR (Bada et al. 2010) with NNE-SSW compression and WNW-ESE extension. 